Prepared in cooperation with the Missouri Department of Natural Resources

\title{
Quality of Surface Water in Missouri, Water Year 2012
}

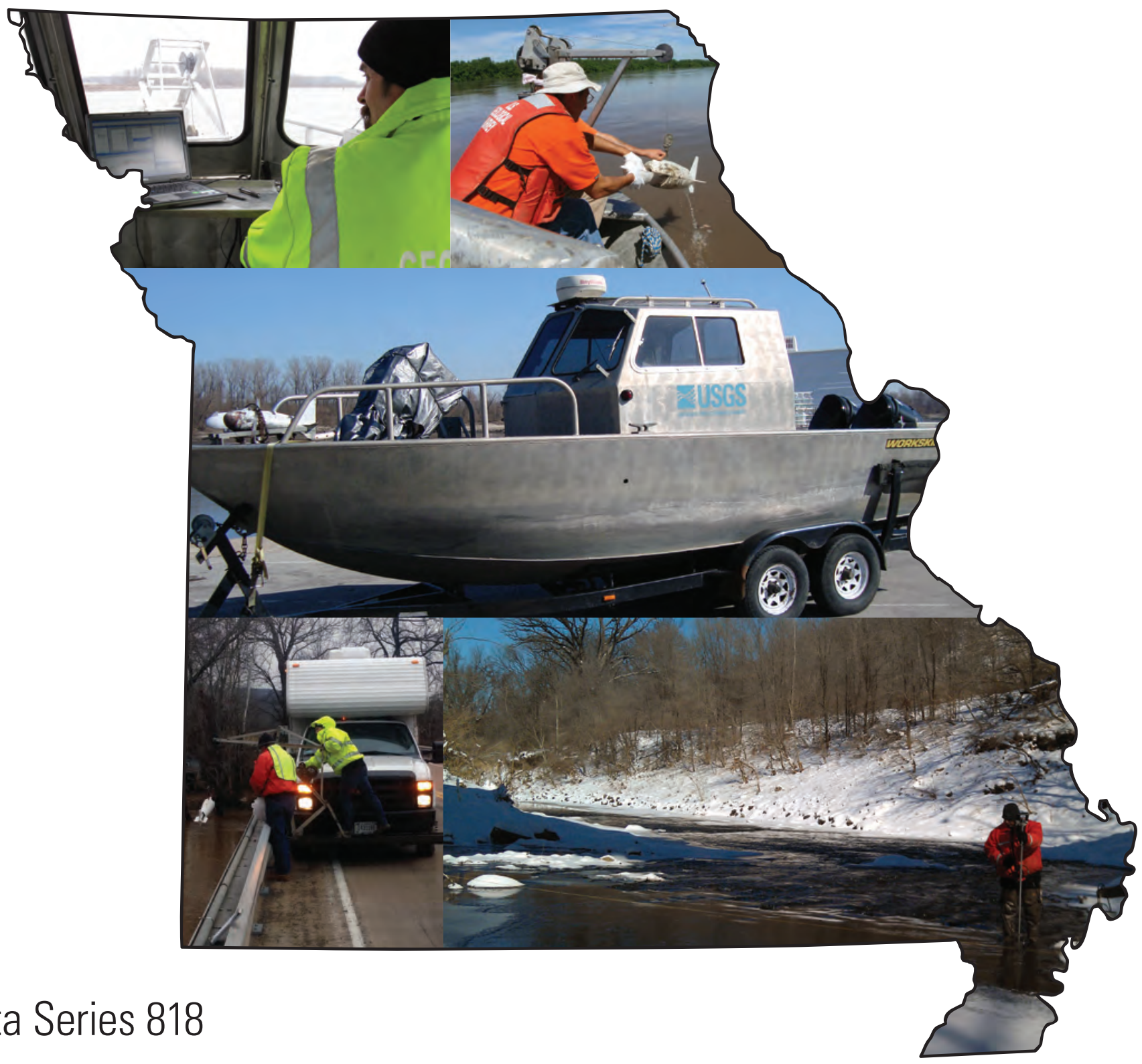

U.S. Department of the Interior

U.S. Geological Survey 


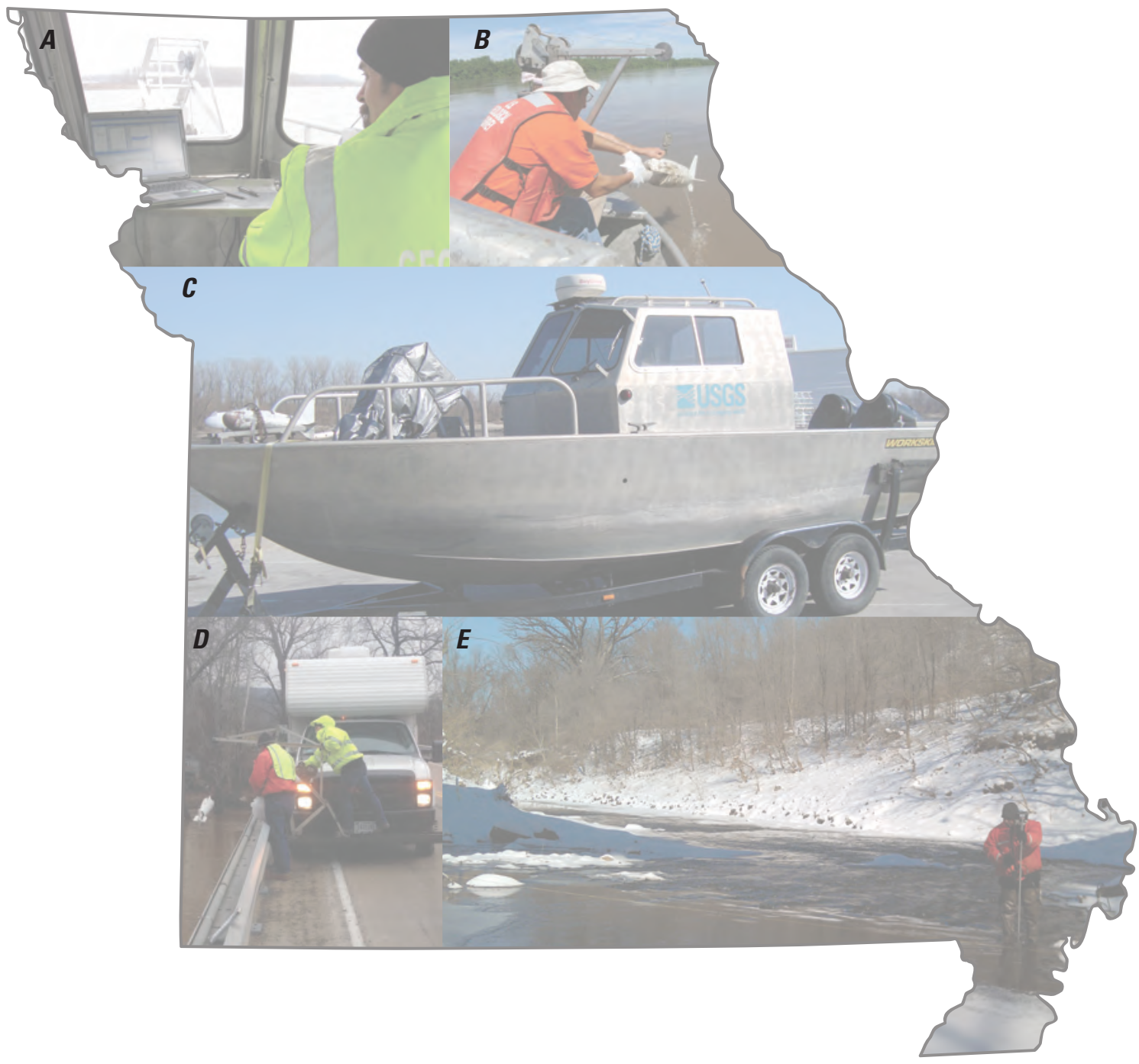

Cover photographs. $A$, Hydrologic technician recording a streamflow measurement on the Mississippi River; $B$, Hydrologic technician collecting water-quality sample on the Missouri River; $C$, Boat used for sampling on Missouri and Mississippi Rivers; $D$, Collecting a sediment sample during a storm event; and $E$, Hydrologic technician measuring streamflow in winter. 


\section{Quality of Surface Water in Missouri, Water Year 2012}

By Miya N. Barr

Prepared in cooperation with the Missouri Department of Natural Resources

Data Series 818

U.S. Department of the Interior

U.S. Geological Survey 


\title{
U.S. Department of the Interior SALLY JEWELL, Secretary
}

\section{U.S. Geological Survey Suzette M. Kimball, Acting Director}

\author{
U.S. Geological Survey, Reston, Virginia: 2014
}

For more information on the USGS - the Federal source for science about the Earth, its natural and living resources, natural hazards, and the environment, visit http://www.usgs.gov or call 1-888-ASK-USGS.

For an overview of USGS information products, including maps, imagery, and publications, visit http://www.usgs.gov/pubprod

To order this and other USGS information products, visit http://store.usgs.gov

Any use of trade, firm, or product names is for descriptive purposes only and does not imply endorsement by the U.S. Government.

Although this information product, for the most part, is in the public domain, it also may contain copyrighted materials as noted in the text. Permission to reproduce copyrighted items must be secured from the copyright owner.

Suggested citation:

Barr, M.N., 2014, Quality of surface water in Missouri, water year 2012: U.S. Geological Survey Data Series 818 ,

24 p., http://dx.doi.org/10.3133/ds818.

ISSN 2327-638X (online) 


\section{Contents}

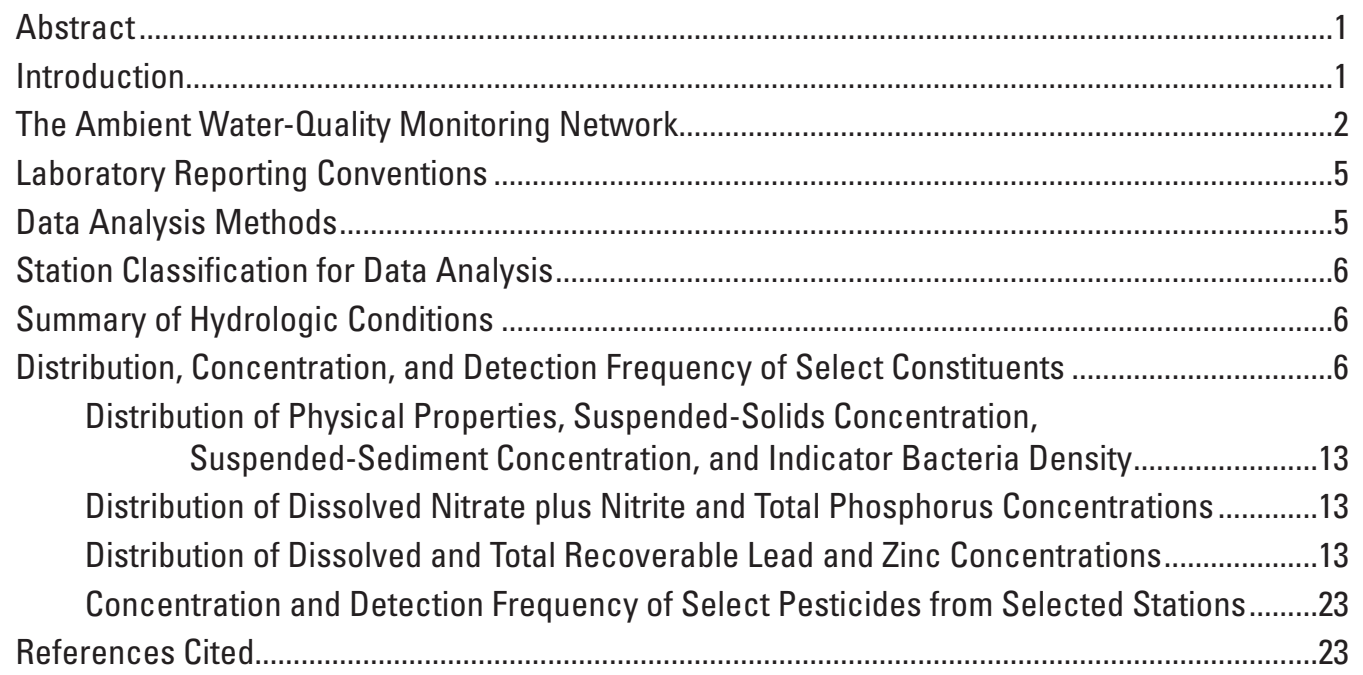

\section{Figures}

1. Map showing location and class of selected stations and physiographic regions

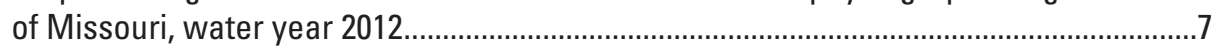

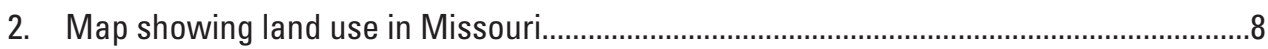

3. Map showing location of streamflow-gaging stations used for the description of hydrologic summary for Missouri, water year 2012 .......................................................10

4. Graphs showing the 2012 water year monthly mean streamflow and long-term median of monthly mean streamflow at six representative streamgages.......................11

5. Boxplots showing distribution of physical properties, suspended-solids concentrations, suspended-sediment concentrations, and indicator bacteria densities in samples from 78 stations, water year 2012 ................................................14

6. Boxplots showing distribution of dissolved nitrate plus nitrite as nitrogen and total phosphorus concentrations in samples from 78 stations, water year 2012.............16

7. Boxplots showing distribution of dissolved and total recoverable lead and zinc

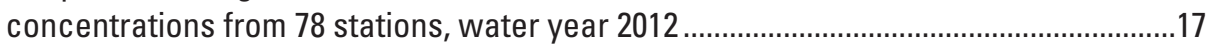

8. Graphs showing detection of select pesticides from selected stations, water year 2012

\section{Tables}

1. U.S. Geological Survey (USGS) station number, name, drainage area, and sampling frequency of 78 selected stations in Missouri, water year 2012 ........................

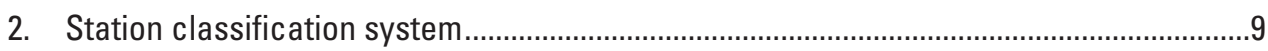

3. Peak discharge for the $\mathbf{2 0 1 2}$ water year and select periods of record for selected streamgages

4. Seven-day low flow for water year 2012, period of record 7-day low flow, and period of record minimum daily mean flow for selected streamgages in Missouri 


\section{Conversion Factors}

Inch/Pound to SI

\begin{tabular}{|c|c|c|}
\hline Multiply & By & To obtain \\
\hline \multicolumn{3}{|c|}{ Length } \\
\hline inch (in.) & 2.54 & centimeter $(\mathrm{cm})$ \\
\hline mile (mi) & 1.609 & kilometer $(\mathrm{km})$ \\
\hline \multicolumn{3}{|c|}{ Area } \\
\hline square mile $\left(\mathrm{mi}^{2}\right)$ & 2.590 & square kilometer $\left(\mathrm{km}^{2}\right)$ \\
\hline \multicolumn{3}{|c|}{ Flow rate } \\
\hline cubic foot per second $\left(\mathrm{ft}^{3} / \mathrm{s}\right)$ & 0.02832 & cubic meter per second $\left(\mathrm{m}^{3} / \mathrm{s}\right)$ \\
\hline
\end{tabular}

Temperature in degrees Celsius $\left({ }^{\circ} \mathrm{C}\right)$ may be converted to degrees Fahrenheit $\left({ }^{\circ} \mathrm{F}\right)$ as follows:

$$
{ }^{\circ} \mathrm{F}=\left(1.8 x^{\circ} \mathrm{C}\right)+32
$$

Horizontal coordinate information is referenced to the North American Datum of 1983 (NAD 83).

Specific conductance is given in microsiemens per centimeter at 25 degrees Celsius $(\mu \mathrm{S} / \mathrm{cm}$ at $\left.25^{\circ} \mathrm{C}\right)$.

Concentrations of chemical constituents in water are given either in milligrams per liter (mg/L) or micrograms per liter $(\mu \mathrm{g} / \mathrm{L})$.

\section{Abbreviations}

$\begin{array}{ll}\text { AWOMN } & \text { Ambient Water-Quality Monitoring Network } \\ \text { CIAT } & \text { 2-Chloro-4-isopropylamino-6-amino-s-triazine } \\ \text { CWA } & \text { Clean Water Act } \\ \text { DO } & \text { dissolved oxygen } \\ \text { EPTC } & \text { S-ethyl dipropylthiocarbamate } \\ \text { LRL } & \text { laboratory reporting level } \\ \text { LT-MDL } & \text { long-term method detection level } \\ \text { MDL } & \text { minimum detection level } \\ \text { MDNR } & \text { Missouri Department of Natural Resources } \\ \text { MRL } & \text { minimum reporting level } \\ \text { NASQAN } & \text { National Stream Quality Assessment Network } \\ \text { NWIS } & \text { National Water Information System } \\ \text { NWISWeb } & \text { National Water Information System Web Interface } \\ \text { NWOL } & \text { National Water Quality Laboratory } \\ \text { TMDL } & \text { total maximum daily load } \\ \text { USGS } & \text { U.S. Geological Survey }\end{array}$




\title{
Quality of Surface Water in Missouri, Water Year 2012
}

\author{
By Miya N. Barr
}

\section{Abstract}

The U.S. Geological Survey, in cooperation with the Missouri Department of Natural Resources, designed and operates a series of monitoring stations on streams and springs throughout Missouri known as the Ambient Water-Quality Monitoring Network. During the 2012 water year (October 1, 2011, through September 30,2012), data were collected at 81 stations - 73 Ambient Water-Quality Monitoring Network stations, 6 alternate Ambient Water-Quality Monitoring Network stations, and 2 U.S. Geological Survey National Stream Quality Accounting Network stations. Dissolved oxygen, specific conductance, water temperature, suspended solids, suspended sediment, fecal coliform bacteria, Escherichia coli bacteria, dissolved nitrate plus nitrite as nitrogen, total phosphorus, dissolved and total recoverable lead and zinc, and select pesticide compound summaries are presented for 78 of these stations. The stations primarily have been classified into groups corresponding to the physiography of the State, primary land use, or unique station types. In addition, a summary of hydrologic conditions in the State including peak discharges, monthly mean discharges, and 7-day low flow is presented.

\section{Introduction}

The U.S. Geological Survey (USGS), in cooperation with the Missouri Department of Natural Resources (MDNR), collects surface-water quality data pertaining to Missouri's water resources each water year (October 1 through September 30). These data, stored and maintained in the USGS National Water Information System (NWIS) database, are collected as part of the Missouri Ambient Water-Quality Monitoring Network (AWQMN) and constitute a source of reliable, impartial, and timely information for developing an enhanced understanding of the State's water resources. To make this information readily available, these data were published annually in the Water-Data Report series from water years 1964 through 2005 (U.S. Geological Survey, 1964-2005). Published data for the 2006 through 2010 water years can be accessed at $h t t p: / / w d r$ water. usgs.gov (U.S. Geological Survey, 2006-2010). Beginning in the 2011 water year, discrete water-quality data are no longer published annually, but can be accessed on the National Water Information System Web Interface (NWISWeb) at http://nwis. waterdata.usgs.gov/mo/nwis/qwdata.

The MDNR is responsible for the implementation of the Federal Clean Water Act (CWA) in Missouri. Section 305(b) of the CWA requires that each State develop a water-quality monitoring program and periodically report the status of its water quality (U.S. Environmental Protection Agency, 1997). Water-quality status is described in terms of the suitability of the water for various uses, such as drinking, fishing, swimming, and support of aquatic life; these uses formally are defined as "designated uses" in State and Federal Regulations. Section 303(d) of the CWA requires certain waters that do not meet applicable water-quality standards be identified, and total maximum daily loads (TMDLs) be determined for these waters (U.S. Environmental Protection Agency, 1997). Total maximum daily loads establish the maximum amount of an impairing substance that a waterbody can assimilate and still meet the water-quality standards. A TMDL addresses a single pollutant for each waterbody.

Missouri has an area of approximately 69,000 square miles $\left(\mathrm{mi}^{2}\right)$ and an estimated population of 6 million people (U.S. Census Bureau, 2012). Within Missouri, there are 24,431 miles (mi) of classified streams that support a variety of uses including wildlife, recreation, agriculture, industry, transportation, and public utilities. An estimated 8,745 mi of streams are adversely affected (impaired) by various physical changes or chemical contaminants to the point that criteria for at least one of the designated uses no longer can be met (Missouri Department of Natural Resources, 2012a). The impairment of about 5,441 mi of assessed streams has been documented by data that meet the requirements of Missouri's 303(d) Listing Methodology. There also are about 3,304 mi of classified, unassessed streams suspected of nonsupport, for which some data have been collected but the data are not of sufficient quality or quantity to officially rate the stream as impaired. Many of the unassessed streams suspected of nonsupport have been affected or modified by agriculture (Missouri Department of Natural Resources, 2012a). 
The purpose of this report is to summarize surface-water quality data collected by the USGS in cooperation with the MDNR, USGS, and U.S. Army Corps of Engineers for water year 2012. The annual summary of select constituents provides MDNR with current information to assess the quality of surface water within the State and to ensure the objectives of the AWQMN are being met. This report is one in a series of annual summaries (Otero-Benítez and Davis, 2009a, 2009b; Barr, 2010, 2011, 2012). Data on the physical characteristics and water-quality constituents in samples collected at 78 surface-water stations are presented in figures and tables. These 78 stations primarily were classified into groups corresponding to the physiography of the State, primary land use, or unique station types.

\section{The Ambient Water-Quality Monitoring Network}

The USGS, in cooperation with the MDNR, designed and operates the cooperative AWQMN, which is a series of monitoring stations on streams and springs throughout Missouri. Constituent concentration data from the AWQMN have been used to determine statewide water-quality status and long-term trends (Barr and Davis, 2010) to meet information needs of State agencies involved in water-quality planning and management. The data collected also provide support for the design, implementation, and evaluation of preventive and remediation programs.

The objectives of the AWQMN are to obtain data on the quality and quantity of surface water within the State; provide a historical database of water-quality information that can be used by the State planning and management agencies to make informed decisions about anthropogenic effects (agriculture, mining, urban) on the State's surface waters; and provide for consistent methodology in data collection, laboratory analysis, and data reporting.

The MDNR and the USGS established a fixed-station AWQMN in 1964 with 18 stations, 5 of which are still currently (2013) being sampled. During the 2012 water year, the program consisted of 73 stations. Alternate sampling stations have been established at other streamflow-gaging stations within the area of some primary stations, and were sampled due to drought conditions in the summer months of 2012, which classified Missouri as having a severe to extreme drought by the National Drought Mitigation Center (2013). Some alternate stations also are primary stations within the AWQMN (table 1). Six stations that are not part of the AWQMN were sampled when the primary stations had no measureable streamflow-Middle Fork Grand River near Albany (06896190), No Creek at Farmersville (06899585), Mussel Fork near Musselfork (06906000), Marmaton River near Nevada (06918060), South Grand River at Urich (06921600), and Marais des Cygnes River near Rich Hill
(06916665). In addition to the AWQMN stations, water samples are collected by the USGS at two USGS National Stream Quality Accounting Network (NASQAN; a national water-quality sampling network operated by the USGS) stations. From these 81 stations, 78 are included in this report (table 1). Three stations from the AWQMN did not fit in the groups (classes) defined for this report and were not included. The three excluded stations were Cuivre River near Troy (05514500) and Lamine River near Pilot Grove (06907300), both located in the Ozark Plateaus border, and Lake Taneycomo at Branson (07053700). Sampling frequency (table 1) is determined by a number of factors, including drainage basin size, potential effects from anthropogenic activities (such as agriculture, mining, and urban), history of chemical change, need for short-term data, and cost. Each of the streams in the AWQMN is classified for one or more designated uses. For specific information on the designated uses applicable to the streams sampled in the AWQMN, refer to Missouri Department of Natural Resources (2012a).

The unique eight-digit number used by the USGS to identify each surface-water station is assigned when a station first is established. The complete eight-digit number for each station includes a two-digit prefix that designates the major river system (05 is the Upper Mississippi River, 06 is the Missouri River, and 07 is the Lower Mississippi River) plus a six-digit downstream-order number. For example, the station number 05587455 indicates the station is located on the Upper Mississippi River ("05"), whereas the remaining six digits ("587455") locate the station in downstream order. In this system, the station numbers increase downstream along the main stem. A station on a tributary that enters between two main stem stations is assigned a station number between them.

Methods used for collecting and processing representative water-quality samples are presented in detail in the USGS "National Field Manual for the Collection of Water-Quality Data" (U.S. Geological Survey, variously dated). Onsite measurements of dissolved oxygen (DO), specific conductance, and water temperature were collected at each station according to procedures described in Wilde (chapter sections variously dated). Samples were collected and analyzed for indicator bacteria [Escherichia coli (E. coli) and fecal coliform] were processed using the membrane filtration procedure described in Myers and others (2007). Methods used by the USGS for collecting and processing representative samples for nutrients, major chemical constituents, trace elements, suspended solids, suspended sediment, and pesticide analysis are presented in detail in U.S. Geological Survey (2006), Guy (1969), and Wilde and others (2004). All chemical analyses were done by the USGS National Water Quality Laboratory (NWQL) in Lakewood, Colorado, according to procedures described in Patton and Kryskalla (2011), Patton and Truitt (1992), Garabarino and others (2006), Fishman (1993), Sandstrom and others (2001), and Zaugg and others (1995). Suspended-sediment concentrations were computed according to procedures described in Guy (1969). 
Table 1. U.S. Geological Survey (USGS) station number, name, drainage area, and sampling frequency of 78 selected stations in Missouri, water year 2012.

[mi², square mile; --, not applicable]

\begin{tabular}{|c|c|c|c|c|}
\hline $\begin{array}{c}\text { USGS } \\
\text { station number }\end{array}$ & Station name & $\begin{array}{l}\text { Contributing } \\
\text { drainage } \\
\text { area } \\
\left(\mathrm{mi}^{2}\right)\end{array}$ & $\begin{array}{c}\text { Water } \\
\text { year } 2012 \\
\text { sampling } \\
\text { frequency }\end{array}$ & $\begin{array}{c}\text { USGS station } \\
\text { class } \\
\text { (table 2) }\end{array}$ \\
\hline 05495000 & Fox River at Wayland & 400 & 6 & DTPL ag \\
\hline 05496000 & Wyaconda River above Canton & 393 & 6 & DTPL ag \\
\hline 05497150 & North Fabius River near Ewing & 471 & 6 & DTPL ag \\
\hline 05500000 & South Fabius River near Taylor & 620 & 12 & DTPL ag \\
\hline${ }^{\mathrm{a}} 05587455$ & Mississippi River below Grafton, Illinois & 171,300 & 12 & BRMIG \\
\hline 06817700 & Nodaway River near Graham & 1,520 & 6 & DTPL wi ag \\
\hline a 06818000 & Missouri River at St. Joseph & 426,500 & 12 & BRMOSJ \\
\hline 06821190 & Platte River at Sharps Station & 2,380 & 6 & DTPL wi ag \\
\hline 06894100 & Missouri River at Sibley & 426,500 & 12 & BRMOS \\
\hline 06896187 & Middle Fork Grand River near Grant City & 82.4 & 6 & DTPL ag \\
\hline b06896190 & Middle Fork Grand River near Albany & 195 & 1 & DTPL ag \\
\hline b06898100 & Thompson River at Mount Moriah & 891 & d8 8 & DTPL ag \\
\hline 06898800 & Weldon River near Princeton & 452 & 6 & DTPL ag \\
\hline 06899580 & No Creek near Dunlap & 34.0 & 12 & DTPL ag \\
\hline b06899585 & No Creek at Farmersville & 67.0 & 1 & DTPL ag \\
\hline 06899950 & Medicine Creek near Harris & 192 & 12 & DTPL ag \\
\hline 06900100 & Little Medicine Creek near Harris & 66.5 & 12 & DTPL ag \\
\hline 06900900 & Locust Creek near Unionville & 77.5 & 12 & DTPL ag \\
\hline 06902000 & Grand River near Sumner & 6,880 & 12 & DTPL wi ag \\
\hline 06905500 & Chariton River near Prairie Hill & 1,870 & 6 & DTPL wi ag \\
\hline 06905725 & Mussel Fork near Mystic & 24.0 & 12 & DTPL ag \\
\hline b06906000 & Mussel Fork near Musselfork & 267 & 5 & DTPL ag \\
\hline 06906300 & East Fork Little Chariton River near Huntsville & 220 & 6 & DTPL ag \\
\hline b06916665 & Marais des Cygnes River near Rich Hill & 3,250 & 1 & OSPL wi ag \\
\hline 06917630 & East Drywood Creek at Prairie State Park & 3.38 & 4 & OSPL pr \\
\hline b06918060 & Marmaton River near Nevada & 1,074 & 2 & OSPL wi ag \\
\hline 06918070 & Osage River above Schell City & 5,410 & 6 & OSPL wi ag \\
\hline 06918600 & Little Sac River near Walnut Grove & 119 & 12 & OZPLSP ag/fo \\
\hline 06919500 & Cedar Creek near Pleasant View & 420 & 12 & OZPLSP ag/fo \\
\hline 06921070 & Pomme de Terre River near Polk & 276 & 9 & OZPLSA fo/ag \\
\hline 06921590 & South Grand River at Archie & 356 & 6 & OSPL ag \\
\hline b06921600 & South Grand River at Urich & 670 & 2 & OSPL ag \\
\hline
\end{tabular}


Quality of Surface Water in Missouri, Water Year 2012

Table 1. U.S. Geological Survey (USGS) station number, name, drainage area, and sampling frequency of 78 selected stations in Missouri, water year 2012.-Continued

$\left[\mathrm{mi}^{2}\right.$, square mile; --, not applicable]

\begin{tabular}{|c|c|c|c|c|}
\hline $\begin{array}{c}\text { USGS } \\
\text { station number }\end{array}$ & Station name & $\begin{array}{l}\text { Contributing } \\
\text { drainage } \\
\text { area } \\
\left(\mathrm{mi}^{2}\right)\end{array}$ & $\begin{array}{c}\text { Water } \\
\text { year } 2012 \\
\text { sampling } \\
\text { frequency }\end{array}$ & $\begin{array}{c}\text { USGS station } \\
\text { class } \\
\text { (table 2) }\end{array}$ \\
\hline 06921720 & Big Creek near Blairstown & 414 & 12 & OSPL ag \\
\hline 06923700 & Niangua River at Bennett Spring & 441 & 6 & OZPLSA fo/ag \\
\hline 06926510 & Osage River below St. Thomas & 14,580 & 6 & OZPLSA wi fo/ag \\
\hline 06927850 & Osage Fork of the Gasconade River near Lebanon & 43.6 & 6 & OZPLSA fo/ag \\
\hline 06928440 & Roubidoux Spring at Waynesville & -- & 6 & SPRING \\
\hline 06930450 & Big Piney River at Devil's Elbow & 746 & 9 & OZPLSA fo/ag \\
\hline 06930800 & Gasconade River above Jerome & 2,570 & 12 & OZPLSA wi fo/ag \\
\hline a,c 06934500 & Missouri River at Hermann & 522,500 & 16 & $\mathrm{BRMOH}$ \\
\hline 07014000 & Huzzah Creek near Steelville & 259 & 6 & OZPLSA fo/ag \\
\hline 07014200 & Courtois Creek at Berryman & 173 & 6 & OZPLSA fo/ag \\
\hline 07014500 & Meramec River near Sullivan & 1,475 & 12 & OZPLSA wi fo/ag \\
\hline 07016400 & Bourbeuse River above Union & 808 & 9 & OZPLSA fo/ag \\
\hline 07018100 & Big River near Richwoods & 735 & 9 & MINING \\
\hline 07019280 & Meramec River at Paulina Hills & 3,920 & 12 & URBAN wi \\
\hline 07020550 & South Fork Saline Creek near Perryville & 55.3 & 6 & OZPLSA fo/ag \\
\hline 07021020 & Castor River at Greenbriar & 423 & 6 & OZPLSA fo/ag \\
\hline a,c 07022000 & Mississippi River at Thebes, Illinois & 713,200 & 12 & BRMIT \\
\hline 07036100 & St. Francis River near Saco & 664 & 9 & OZPLSA fo/ag \\
\hline 07037300 & Big Creek at Sam A. Baker State Park & 189 & 6 & OZPLSA fo/ag \\
\hline 07042450 & St. Johns Ditch at Henderson Mound & 313 & 7 & MIALPL \\
\hline 07046250 & Little River Ditches near Rives & 1,620 & 12 & MIALPL \\
\hline 07050150 & Roaring River Spring at Cassville & -- & 6 & OZPLSP ag/fo \\
\hline 07052152 & Wilson Creek near Brookline & 51 & 12 & URBAN \\
\hline 07052250 & James River near Boaz & 462 & 7 & URBAN \\
\hline 07052345 & Finley Creek below Riverdale & 261 & 12 & OZPLSP ag/fo \\
\hline 07052500 & James River at Galena & 987 & 12 & URBAN \\
\hline 07052820 & Flat Creek below Jenkins & 274 & 12 & OZPLSP ag/fo \\
\hline 07053900 & Swan Creek near Swan & 148 & 6 & OZPLSA fo/ag \\
\hline 07057500 & North Fork River near Tecumseh & 561 & 6 & OZPLSA fo/ag \\
\hline 07057750 & Bryant Creek below Evans & 214 & 6 & OZPLSA fo/ag \\
\hline 07061600 & Black River below Annapolis & 493 & 7 & OZPLSA fo/ag \\
\hline 07066110 & Jacks Fork above Two River & 425 & 12 & OZPLSA fo/ag \\
\hline
\end{tabular}


Table 1. U.S. Geological Survey (USGS) station number, name, drainage area, and sampling frequency of 78 selected stations in Missouri, water year 2012.-Continued

[mi², square mile; --, not applicable]

\begin{tabular}{clccc}
\hline $\begin{array}{c}\text { USGS } \\
\text { station number }\end{array}$ & \multicolumn{1}{c}{ Station name } & $\begin{array}{c}\text { Contributing } \\
\text { drainage } \\
\text { area } \\
\left(\mathbf{m i}^{2}\right)\end{array}$ & $\begin{array}{c}\text { Water } \\
\text { year 2012 } \\
\text { sampling } \\
\text { frequency }\end{array}$ & $\begin{array}{c}\text { USGS station } \\
\text { class } \\
\text { (table 2) }\end{array}$ \\
\hline 07067500 & Big Spring near Van Buren & -- & 4 & SPRING \\
07068000 & Current River at Doniphan & 2,040 & 12 & OZPLSA wi fo/ag \\
07068510 & Little Black River below Fairdealing & 194 & 6 & OZPLSA fo/ag \\
07071000 & Greer Spring at Greer & -- & 4 & SPRING \\
07071500 & Eleven Point River near Bardley & 793 & 6 & OZPLSA fo/ag \\
07185764 & Spring River above Carthage & 425 & 12 & OZPLSP ag/fo \\
07186480 & Center Creek near Smithfield & 303 & 9 & MINING \\
07186600 & Turkey Creek near Joplin & 41.8 & 9 & URBAN \\
07187000 & Shoal Creek above Joplin & 427 & 12 & OZPLSP ag/fo \\
07188653 & Big Sugar Creek near Powell & 141 & 12 & OZPLSP ag/fo \\
07188838 & Little Sugar Creek near Pineville & 195 & 12 & OZPLSP ag/fo \\
07188885 & Indian Creek near Lanagan & 239 & 12 & OZPLSP ag/fo
\end{tabular}

${ }^{a}$ Additional water temperature and suspended-sediment samples collected in cooperation with the U.S. Army Corps of Engineers.

${ }^{b}$ Alternate sampling station used during drought conditions at primary Ambient Water-Quality Monitoring Network station. 06896190 is alternate station for $06896187 ; 06898100$ and 06899585 are alternate stations for $06899580 ; 06906000$ is alternate station for $06905725 ; 06916665$ is alternate station for 06921720; 06918060 is alternate station for 06917630 ; and 06921600 is alternate station for 06921590 .

'Stations 06934500 and 07022000 are not part of the Ambient Water-Quality Monitoring Network, but were used in the report. Stations 06934500 and 07022000 are funded by the U.S. Geological Survey National Stream Quality Account Network.

dStation 06898100 was sampled as a primary station six times and as an alternate station twice during the 2012 water year.

\section{Laboratory Reporting Conventions}

The NWQL uses method reporting conventions (Childress and others, 1999) to establish the minimum concentration for more than which a quantitative measurement can be made. These reporting conventions are the minimum reporting level (MRL) and the laboratory reporting level (LRL). The MRL is defined by the NWQL as the smallest measured concentration of a substance that can be measured reliably using a given analytical method. The method detection level (MDL) is the minimum concentration of a substance that can be measured and reported with 99-percent confidence that the concentration is greater than zero. A long-term method detection level (LT-MDL) is a detection level obtained by determining the standard deviation of 24 or more MDL spiked-sample measurements for an extended period of time. The LRL is computed as twice the LT-MDL.

\section{Data Analysis Methods}

The distribution of select constituent data was graphically displayed using side-by-side boxplots (box and whiskers distributions; Helsel and Hirsch, 2002). The plots show the center of the data (median, the center line of the boxplot), the variation [interquartile range (25th to 75 th percentiles) or the height of the box], the skewness (quartile skew, which is the relative size of the box halves), the spread (upper and lower adjacent values are the vertical lines or whiskers), and the presence or absence of unusual values, or outliers (upper and lower detached and outside values). If the median equals the 25th and 75th percentiles, the boxplot is represented by a single horizontal line. Boxplots with censored data (suspended solids; dissolved nitrate plus nitrite as nitrogen; total phosphorus; and dissolved and total recoverable lead and zinc) were modified by making the lower limit of the box equal to the 
MRL or LT-MDL. For pesticide concentration distributions, censored concentrations (reported as less than the LRL) were included in each distribution as a concentration value equal to the LRL. For some samples, pesticide concentrations are reported as estimated values, which are included in the distribution as a concentration that is plotted below the LRL and above the LT-MDL.

\section{Station Classification for Data Analysis}

The stations primarily were classified in groups corresponding to the physiography of the State (fig. 1), primary land use (fig. 2), or unique station types (fig. 1; table 2). The physiography-based groups include the Dissected Till Plains (DTPL) in the north, the Osage Plains (OSPL) in the west, the Mississippi Alluvial Plain (MIALPL) in the southeast, and between them the Ozark Plateaus. The Ozark Plateaus (Fenneman, 1938) were further subdivided into two distinct groups based on physiographic location - the Salem Plateau (OZPLSA) and the Springfield Plateau (OZPLSP). Landuse groups include mining (MINING) and urban (URBAN) stations, whereas unique station classes refer to springs (SPRING) and the stations located on the big rivers [the Mississippi River (BRMIG and BRMIT) and the Missouri River (BRMOSJ, BRMOS and BRMOH)].

Some additional variability caused by differences in drainage area and land use was observed within physiographic regions; therefore, watershed size and land-use indicators were used to develop a complete set of classes. The land-use indicator provides a subclassification for stations in similar regions with different land uses (fig. 1; table 2). The secondary land-use indicators are watershed indicator stations (wi), which are the most downstream stations in a large watershed, and are defined for the purposes of this report as a drainage area greater than 1,000 $\mathrm{mi}^{2}$; forest (fo); agricultural (ag); and prairie (pr). Observations and analyses from watershed indicator stations can be interpreted as being representative of the general condition of the watershed. In some instances, the agricultural and forest secondary land uses were present; therefore, the convention was to mention them in predominant order. For example, an agriculture and forest (ag/fo) indicator implies that the primary land use of the watershed is agriculture, although a substantial part of the land use is forest.

\section{Summary of Hydrologic Conditions}

Surface-water streamflow varies seasonally in Missouri and tends to reflect precipitation patterns. During the 2012 water year, the average annual precipitation of the conterminous United States was about 2.57 inches (in.) less than the 20th century average, making 2012 the 15 th driest year on record. (National Oceanic and Atmospheric Administration, 2013a). Precipitation in Missouri during the 2012 water year ranked less than normal with 34.67 in. of total precipitation, whereas the long-term State precipitation average is 41.03 in. (National Oceanic and Atmospheric Administration, 2013b). In October 2011, about 40 percent of all Missouri counties had no dry or drought conditions and about 60 percent were classified as abnormally dry. From July through September 2012, 100 percent of Missouri counties reported at least moderate drought conditions. During August 2012, 35 percent of Missouri counties - typically located in the northwest, southwest, and southeast corners of the State-were classified as having extreme drought conditions (National Drought Mitigation Center, 2013).

The selection of streamflow-gaging stations (hereinafter referred to as streamgages) used to describe the variation in hydrologic conditions was based on their geographical distribution across the State and their long period of record. This summary of statewide hydrologic condition data is a legacy of information that was previously provided in the annual WaterData Reports (U.S. Geological Survey, 1964-2005). Stations used for the hydrologic summary are identified in figure 3.

Six streamgages across the State were selected to illustrate the 2012 water year monthly mean streamflow and the long-term median of monthly mean streamflow (fig. 4). Monthly mean streamflow is the arithmetic mean of daily streamflow for a given month. The median of the monthly mean streamflow computed for the available period of record is used to represent the historical data for comparison to the current water year. Of these six stations, three (05495000, 06921590, and 07052500) are part of the AWQMN and the remaining three $(06897500,06933500$, and 07067000) are streamgages only and are not part of the AWQMN (figs. 1 and 3). The six stations had monthly mean streamflow less than the long-term monthly mean streamflow for June through August 2012 (fig. 4). The six stations had monthly mean streamflow greater than the long-term monthly mean streamflow for December 2011. Two stations - 06921590 (South Grand River at Archie) and 07052500 (James River at Galena) had monthly mean streamflow greater than the long-term monthly mean discharges for September 2012 (fig. 4).

Peak streamflow for the 2012 water year and select periods of record are presented for nine streamgages (fig. 3; table 3). The peak streamflow values shown in table 3 were less than the peak streamflow for the period of record at all stations. The 7-day low flow for the period of record, and the minimum daily mean flow for the 2012 water year are presented for selected stations in table 4.

\section{Distribution, Concentration, and Detection Frequency of Select Constituents}

The analyses presented in this report include the following constituents: dissolved oxygen (DO), specific conductance, water temperature, suspended solids, suspended 


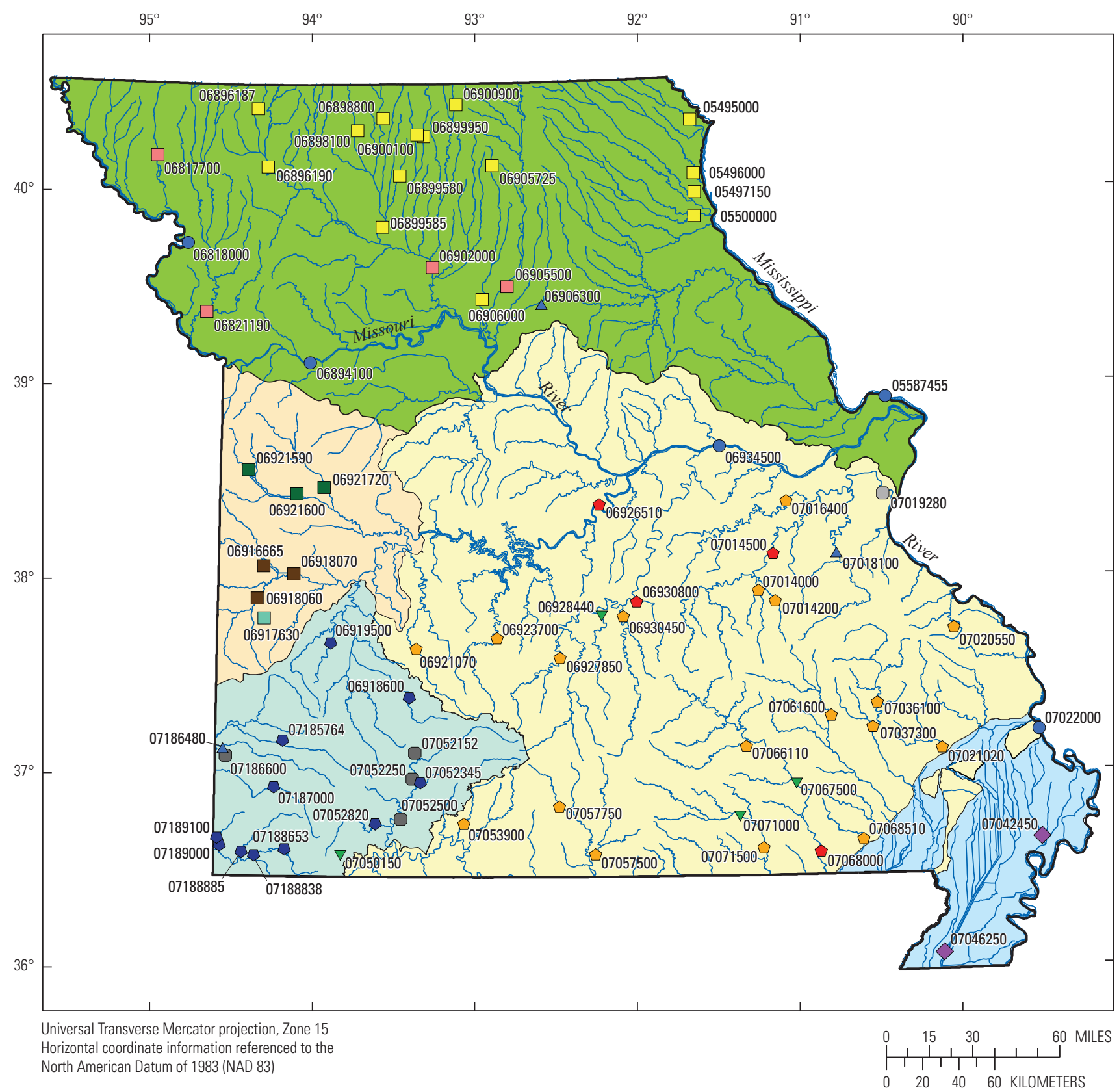

\section{EXPLANATION}

Physiographic regions of Missouri-Modified from Fenneman, 1938

Central Lowland Province-Dissected Till Plains

Central Lowland Province-Osage Plains

Coastal Plain Province—Mississippi Alluvial Plain

Ozark Plateaus Province-Salem Plateau

Ozark Plateaus Province-Springfield Plateau

\section{Ambient Water-Ouality Monitoring Network} (AWOMN) classes (table 2) and station number (05500000)

- Big River (BRMIG, BRMIT, BRMOSJ, BRMOS,

$$
\text { and } \mathrm{BRMOH)}
$$

Mississippi Alluvial Plain (MIALPL)

$\square \quad$ Dissected Till Plains agriculture (DTPL ag)

$\square \quad$ Dissected Till Plains watershed indicator agriculture (DTPL wi ag)

- Osage Plains agriculture (OSPL ag)

- Osage Plains watershed indicator, agriculture

$$
\text { (OSPL wi ag) }
$$

$\square \quad$ Osage Plains prairie (OSPL pr)

Ozark Plateaus - Salem Plateau forest and agriculture (OZPLSA fo/ag)

Ozark Plateaus - Salem Plateau watershed indic ator forest and agriculture (OZPLSA wi fo/ag)

- Ozark Plateaus - Springfield Plateau agriculture and forest (OZPLSP ag/fo)

$\nabla \quad$ Springs (SPRING)

Mining (MINING)

- Urban (URBAN)

Urban watershed indicator (URBAN wi)

Figure 1. Location and class of selected stations and physiographic regions of Missouri, water year 2012. 


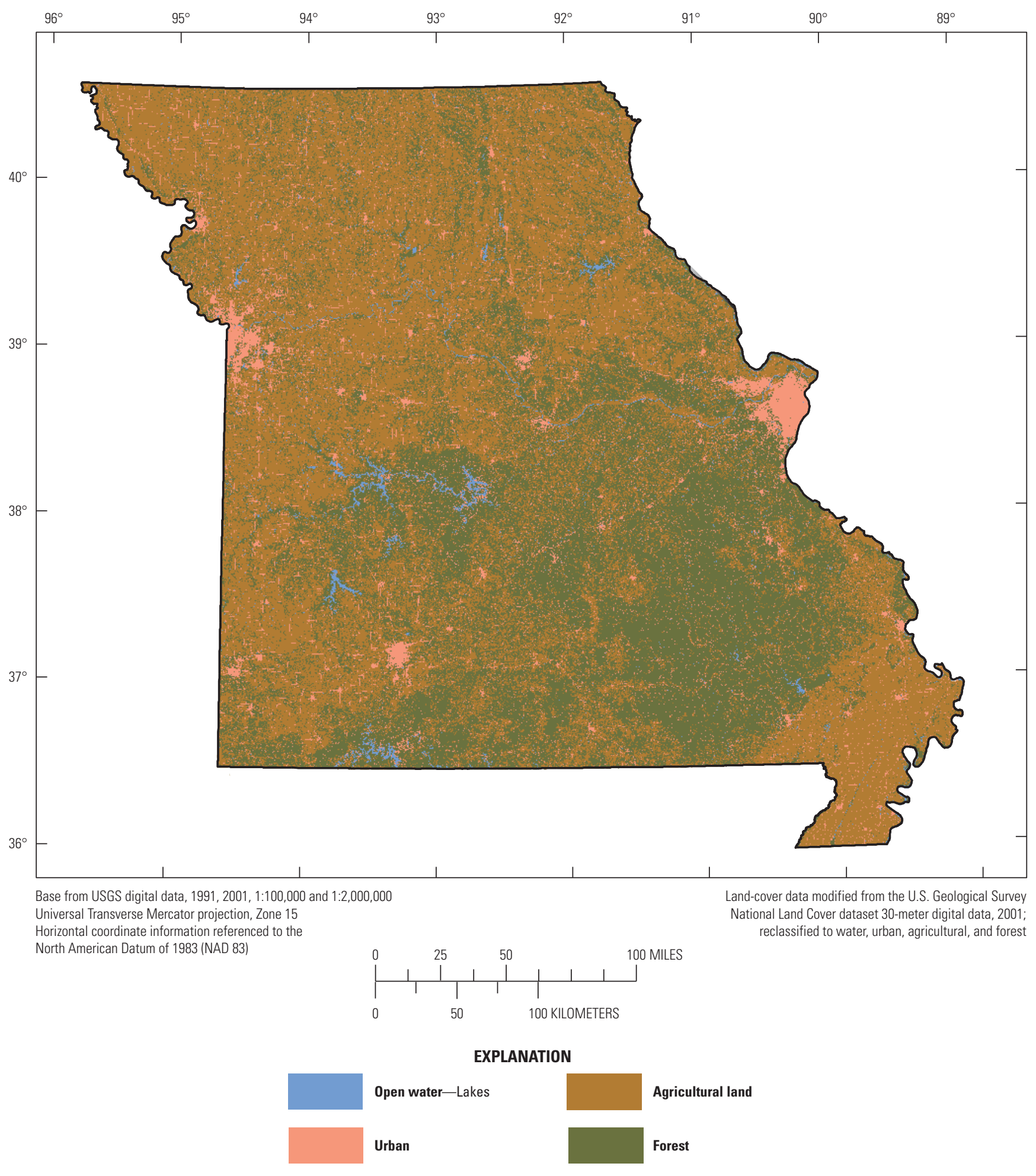

Figure 2. Land use in Missouri. 
Table 2. Station classification system.

[Classification system is based on physiography of the State, primary and secondary land use, unique station type, and watershed size, as well as a station's representativeness to the general condition of the watershed.]

\begin{tabular}{|c|c|c|}
\hline $\begin{array}{c}\text { Class } \\
\text { (fig. 1) }\end{array}$ & Description & $\begin{array}{c}\text { Number of } \\
\text { stations }\end{array}$ \\
\hline BRMIG & Big River-Mississippi River below Grafton, Illinois & 1 \\
\hline BRMIT & Big River-Mississippi River at Thebes, Illinois & 1 \\
\hline BRMOSJ & Big River-Missouri River at St. Joseph, Missouri & 1 \\
\hline BRMOS & Big River-Missouri River at Sibley, Missouri & 1 \\
\hline BRMOH & Big River-Missouri River at Hermann, Missouri & 1 \\
\hline MIALPL & Mississippi Alluvial Plain & a2 \\
\hline OZPLSA fo/ag & Ozark Plateaus - Salem Plateau forest and agriculture & 18 \\
\hline OZPLSA wi fo/ag & Ozark Plateaus - Salem Plateau watershed indicator, forest and agriculture & 4 \\
\hline OZPLSP ag/fo & Ozark Plateaus_-Springfield Plateau agriculture and forest & 12 \\
\hline DTPL ag & Dissected Till Plains agriculture & 15 \\
\hline DTPL wi ag & Dissected Till Plains watershed indicator, agriculture & 4 \\
\hline OSPL ag & Osage Plains agriculture & 3 \\
\hline OSPL wi ag & Osage Plains watershed indicator, agriculture & 3 \\
\hline OSPL pr & Osage Plains prairie & 1 \\
\hline SPRING & Springs & 3 \\
\hline MINING & Mining & 3 \\
\hline URBAN & Urban & 4 \\
\hline URBAN wi & Urban watershed indicator & 1 \\
\hline
\end{tabular}

${ }^{a}$ One station in this class, Little River Ditches near Rives, Missouri (07046250), has a drainage area greater than 1,000 square miles but is not considered a watershed indicator station because the manmade canals and ditches within its drainage area are not hydrologically connected. 


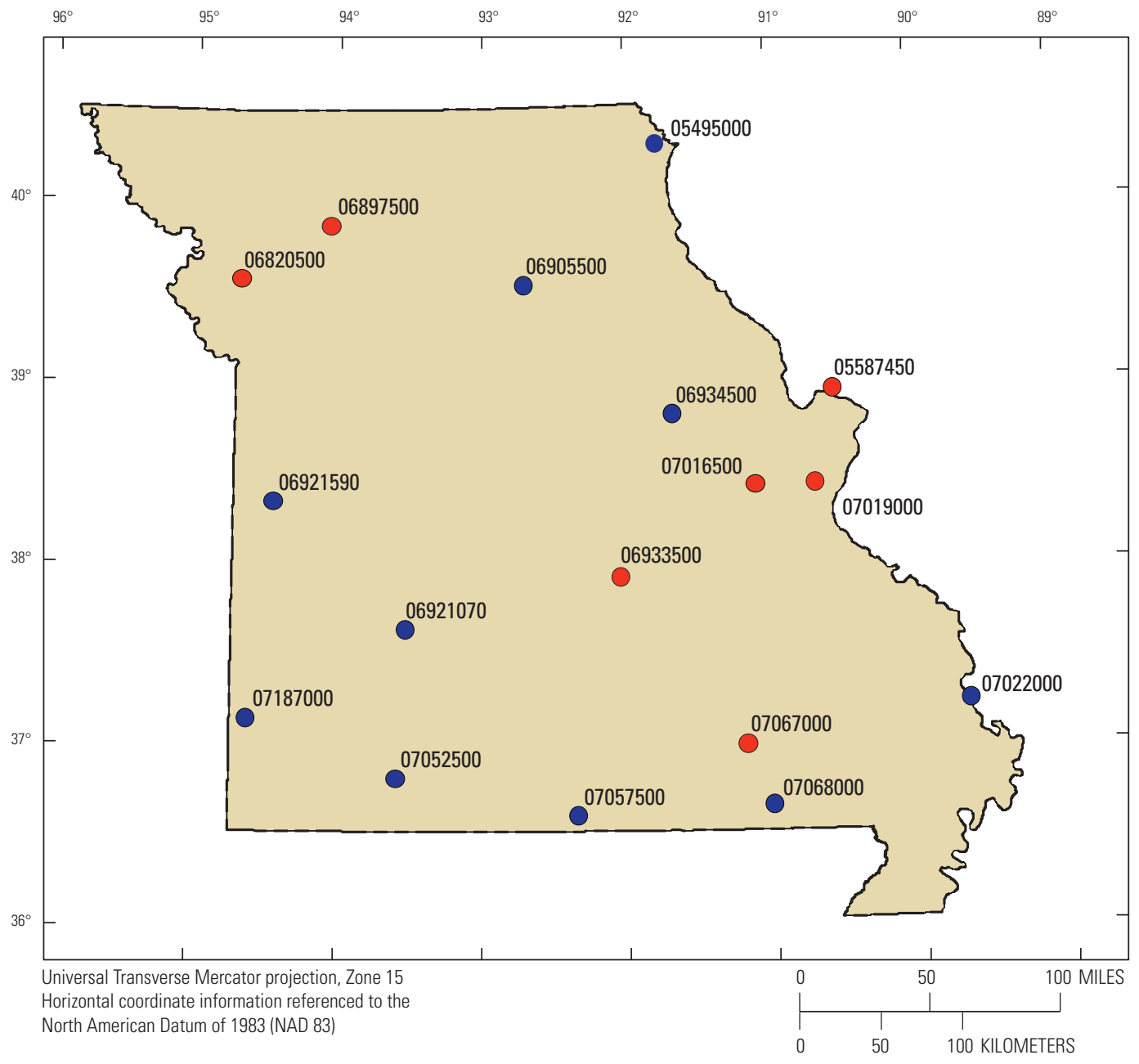

EXPLANATION

Streamflow and water-quality station

- Streamflow station

Figure 3. Location of streamflow-gaging stations used for the description of hydrologic summary for Missouri, water year 2012. 
05495000 Fox River at Wayland
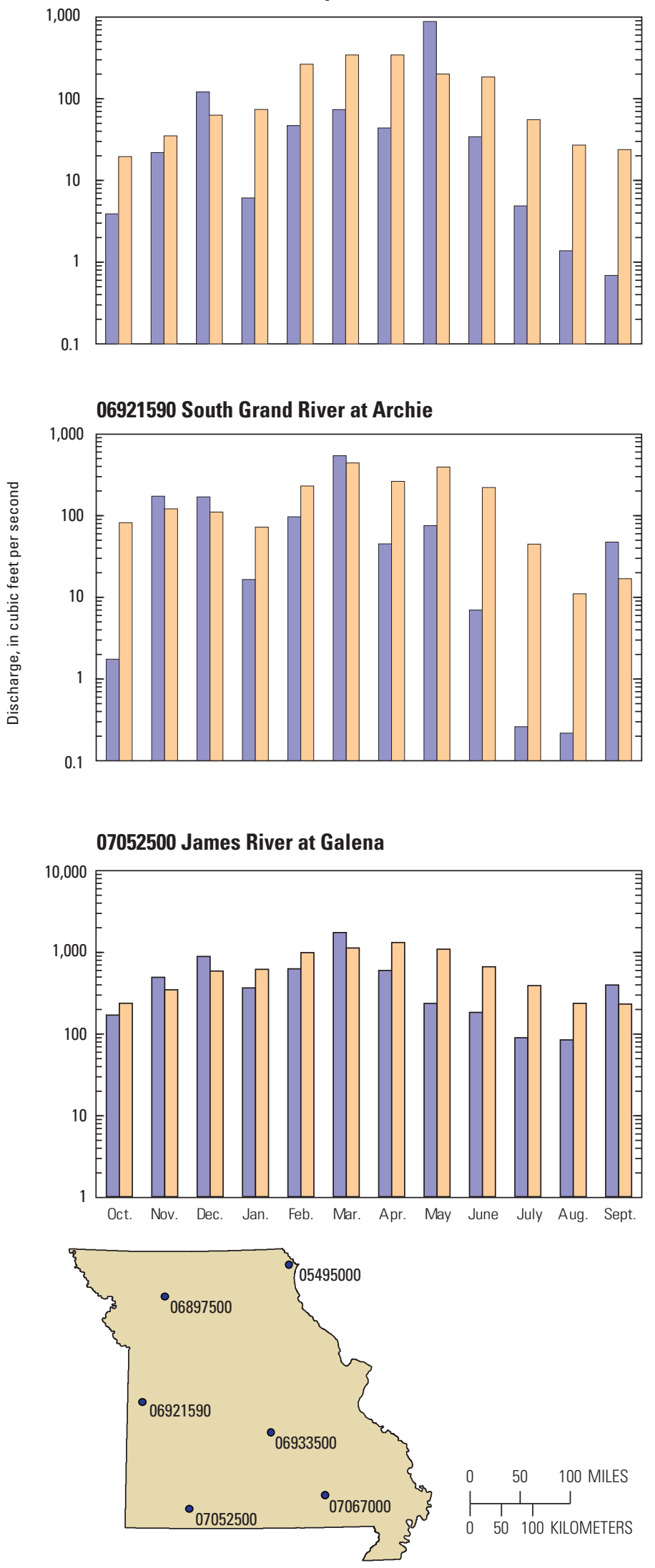

50100 MILES

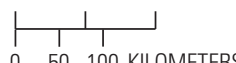

$0 \quad 50100$ KILOMETERS
06897500 Grand River near Gallatin
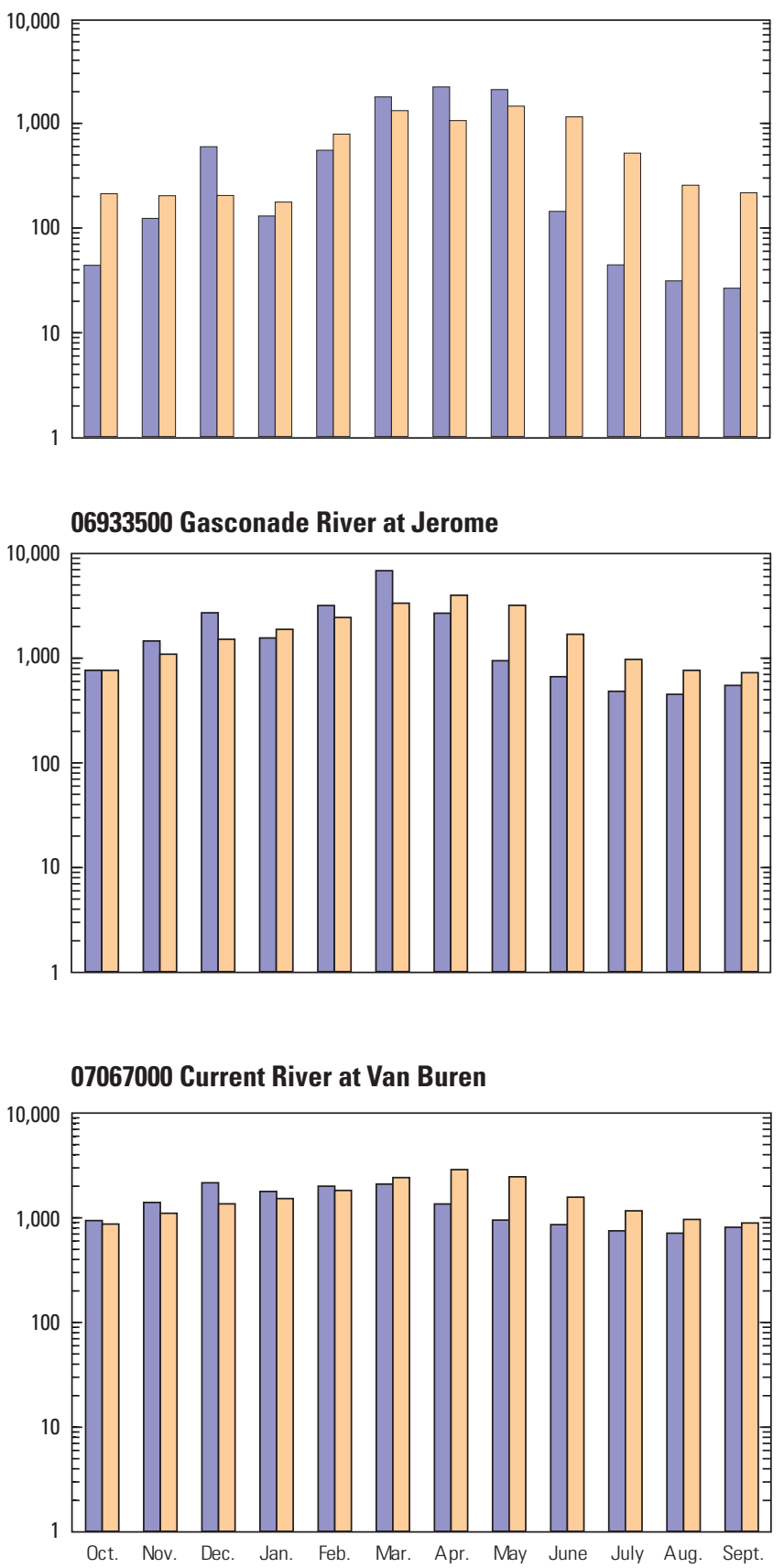

EXPLANATION

Monthly mean streamflow for water year 2012

Median monthly mean streamflow for period of record

Figure 4. The 2012 water year monthly mean streamflow and long-term median of monthly mean streamflow at six representative streamgages. 
Table 3. Peak discharge for the 2012 water year and select periods of record for selected streamgages.

[Peak discharge in cubic feet per second]

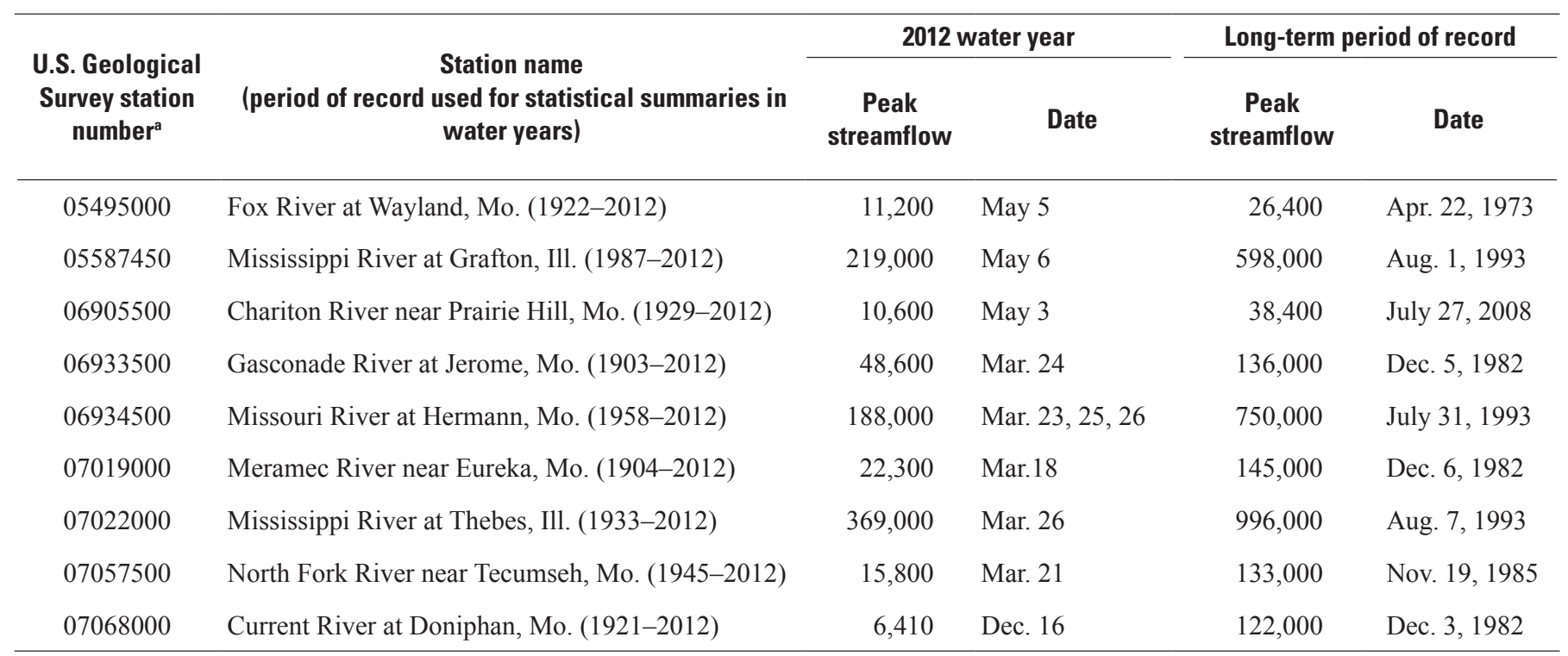

aStations 05587450,06933500 , and 07019000 are streamflow-gaging stations only and not part of the Ambient Water-Quality Monitoring Network (AWQMN).

Table 4. Seven-day low flow for water year 2012, period of record 7-day low flow, and period of record minimum daily mean flow for selected streamgages in Missouri.

[flow in cubic feet per second]

\begin{tabular}{|c|c|c|c|c|c|}
\hline \multirow{2}{*}{$\begin{array}{c}\text { U.S. Geological } \\
\text { Survey station } \\
\text { number }^{\mathrm{a}}\end{array}$} & \multirow{2}{*}{$\begin{array}{c}\text { Station name } \\
\text { (period of record in water years) }\end{array}$} & \multicolumn{2}{|c|}{ 7-day low flow } & \multicolumn{2}{|c|}{ Minimum daily mean flow for period of record } \\
\hline & & 2012 & $\begin{array}{l}\text { Period of } \\
\text { record }\end{array}$ & Streamflow & Date \\
\hline 05495000 & Fox River at Wayland (1922-2012) & 0.19 & 0 & 0 & Several years \\
\hline 06820500 & Platte River near Agency (1933-2012) & 19 & 0 & 0 & Several years \\
\hline 06921070 & Pomme de Terre river near Polk (1969-2012) & 0.21 & 0.21 & 0.17 & Aug. 13, 2012 \\
\hline 07016500 & Bourbeuse River near Union (1921-2012) & 28 & 13 & 12 & Oct. 10,1956 \\
\hline 07067000 & Current River at Van Buren (1912-2012) & 685 & 479 & 476 & Oct. 8,1956 \\
\hline 07187000 & Shoal Creek above Joplin (1942-2012) & 62 & 16 & 15 & Sept. 7, 1954 \\
\hline
\end{tabular}

aStations 06820500,07016500 , and 07067000 are streamflow-gaging stations only and not part of the Ambient Water-Quality Monitoring Network (AWQMN). 
sediment, E. coli bacteria, fecal coliform bacteria, dissolved nitrate plus nitrite as nitrogen (hereinafter referred to as nitrate plus nitrite), total phosphorus, and dissolved and total recoverable lead and zinc. Boxplots of these constituents are presented for the different classes (figs. 5-7). In addition, pesticide data were analyzed from eight stations. Of the 85 pesticide constituents analyzed during the water year, 20 had concentrations larger than their LRL and are presented in this report: 2-chloro-4-isopropylamino-6-amino-s-triazine (CIAT; a degradation product of atrazine); 3,4-dichloroaniline, acetochlor; alachlor; atrazine; cis-propiconazole; cypermethrin; dicrotophos; S-ethyl dipropylthiocarbamate (EPTC); ethoprop; metalaxyl; methyl parathion; metoalachlor; metribuzin; prometon; prometryn; propanil; simazine; terbuthylazine; and trans-propiconazole (fig. 8). Missouri water-quality standards are not shown on the graphs because these standards are not applicable to all streams in the AWQMN network. For specific information on Missouri water-quality standards, refer to Missouri Department of Natural Resources (2012b).

\section{Distribution of Physical Properties, Suspended- Solids Concentration, Suspended-Sediment Concentration, and Indicator Bacteria Density}

The physical properties analyzed for this report were DO, specific conductance, and water temperature. The median DO, in percent saturation, ranged from 78 to 108 percent (fig. 5). Samples from URBAN wi stations had the lowest median DO percent saturation values, whereas samples from URBAN stations had the highest median DO (fig. 5). The range in DO percent saturation values was smallest at BRMIT. Median specific conductance values varied substantially among the station classes (fig. 5), ranging from 105 microsiemens per centimeter at 25 degrees Celsius at the OSPL pr station to 773 microsiemens per centimeter at 25 degrees Celsius at the BRMOSJ station. Median water temperature values ranged from 11.8 to 22.4 degrees Celsius, with the smallest median measured at the OSPL pr station and the largest median measured at the OSPL wi ag stations (fig. 5). The range in water temperature at the SPRING stations was much smaller than at any other station class.

Suspended solids and suspended sediment are measures of the solid material suspended in the water column. These two measures are not considered directly comparable because of differences in collection and analytical techniques. Suspended-solids concentrations were determined at all stations except BRMIT and BRMOH. Median suspended-solids concentrations varied considerably between all station classes, ranging from 15 to 110 milligrams per liter $(\mathrm{mg} / \mathrm{L})$. Samples collected at the OZPL (SA fo/ag, SA wi fo/ag, and SP ag/ fo), OSPL pr, SPRING, MINING, and URBAN stations had median concentrations less than the MRL and data distributions such that boxplots could not be generated. The BRMOS station had the largest median suspended-solids concentrations. Suspended-sediment concentrations were determined only at four Big River stations. The suspended-sediment data used for this report consist of composited cross-sectional concentrations or average cross-sectional concentrations computed from five verticals within the cross-section. Additional suspended-sediment concentrations from individual verticals within cross-sections are available on NWISWeb. Median suspended-sediment concentrations ranged from $45 \mathrm{mg} / \mathrm{L}$ at BRMIG to $299 \mathrm{mg} / \mathrm{L}$ at BRMOSJ (fig. 5).

Median E. coli and fecal coliform bacteria densities ranged from 3.5 to 915 colonies per 100 milliliters (fig. 5). The smallest median densities were in samples collected at SPRING stations, whereas the largest median densities were in samples collected at BRMOS (fig. 5). Median E. coli and fecal coliform bacteria densities varied considerably between all station classes.

\section{Distribution of Dissolved Nitrate plus Nitrite and Total Phosphorus Concentrations}

Samples were collected at all stations for the analysis of nutrients, including dissolved nitrate plus nitrite and total phosphorus. Median dissolved nitrate plus nitrite and total phosphorus concentrations varied considerably between all station classes (fig. 6), ranging from 0.08 to $4.3 \mathrm{mg} / \mathrm{L}$ for nitrate plus nitrite and 0.02 to $0.31 \mathrm{mg} / \mathrm{L}$ for total phosphorus. The smallest median dissolved nitrate plus nitrite concentrations were detected at DTPL ag stations, and the largest concentrations were detected in samples collected at URBAN stations (fig. 6). The smallest median total phosphorus concentrations were detected at the OZPLSA (fo/ag and wi fo/ag) and SPRING stations, all of which had median values equal to the LT-MDL, and the largest median concentration was at the BRMOS station. (fig. 6).

\section{Distribution of Dissolved and Total Recoverable Lead and Zinc Concentrations}

Samples were collected for the analysis of dissolved and total recoverable trace elements, including lead and zinc. No dissolved or total recoverable lead and zinc samples were collected at BRMIT and BRMOH. Median concentration ranges of dissolved and total recoverable lead and zinc (fig. 7) were less than 0.025 to 0.52 micrograms per liter $(\mu \mathrm{g} / \mathrm{L})$ dissolved lead, 0.05 to $10.9 \mu \mathrm{g} / \mathrm{L}$ total recoverable lead, less than 1.4 to $12.9 \mu \mathrm{g} / \mathrm{L}$ dissolved zinc, and less than 3.0 to $14.2 \mu \mathrm{g} / \mathrm{L}$ total recoverable zinc. The smallest median concentrations of dissolved lead and zinc generally were detected in samples collected at BRMOS, MIALPL, DTPL ag, OZPL (SA fo/ag, SA wi fo/ag, SP ag/fo), and SPRING stations (fig. 7). Median dissolved zinc concentrations were detected at or less than the LT-MDL for all samples collected at BRMIG, BRMOSJ, BRMOS, DTPL wi ag, and OSPL ag stations. Although large median concentrations of trace elements were detected at the MINING stations, median concentrations of dissolved and 


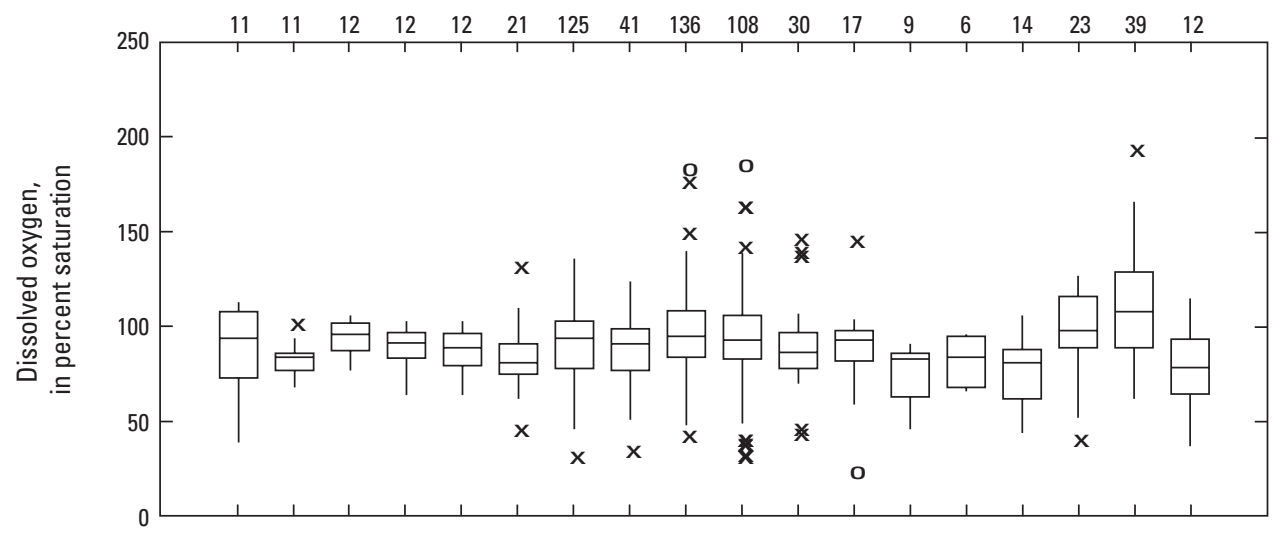

EXPLANATION

12 Number of samples

o Upper detached

X Upper outside Upper adjacent

75th percentile

Median

25th percentile

Lower adjacent

$x \quad$ Lower outside

o Lower detached
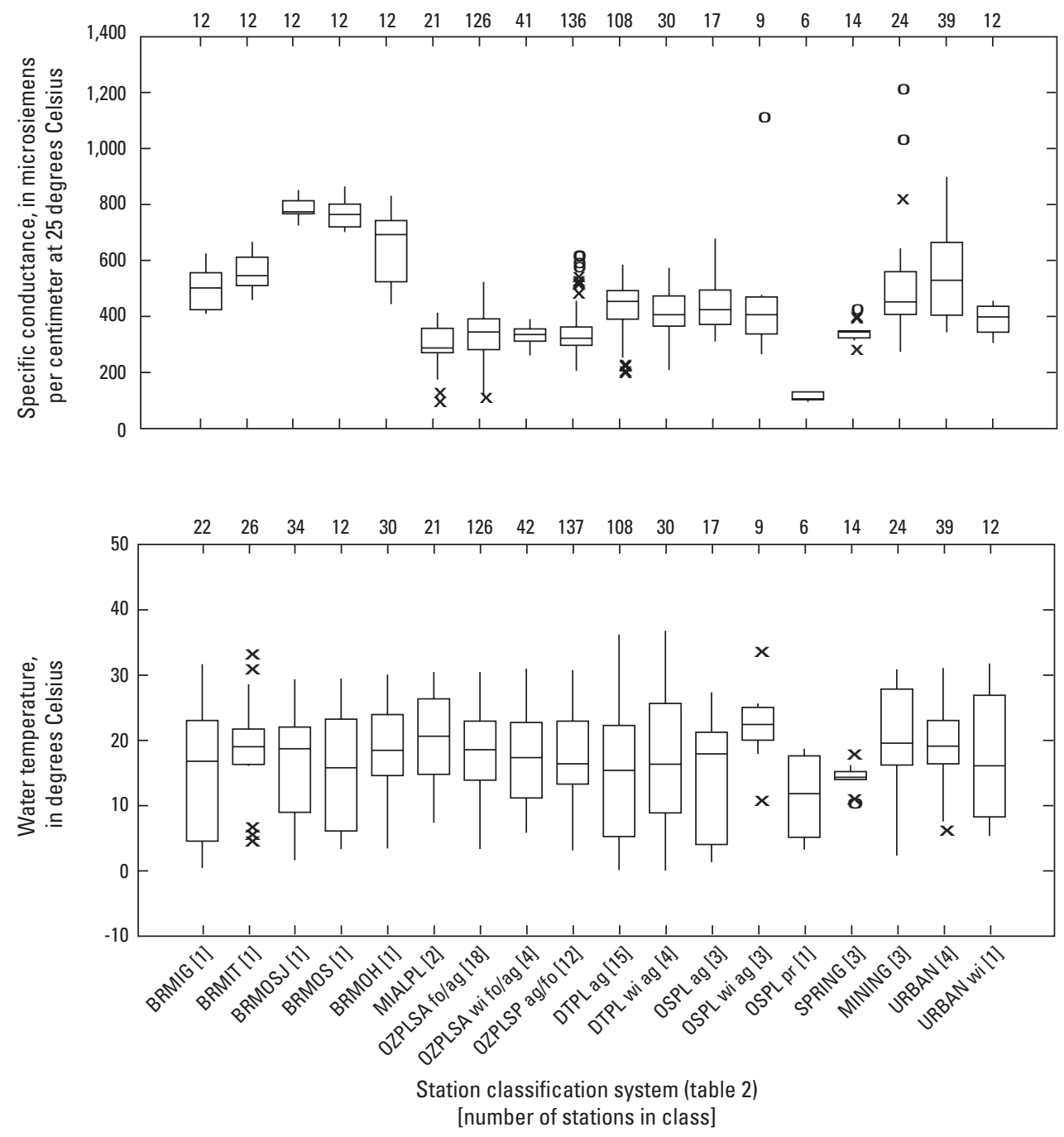

Figure 5. Distribution of physical properties, suspended-solids concentrations, suspended-sediment concentrations, and indicator bacteria densities in samples from 78 stations, water year 2012. 

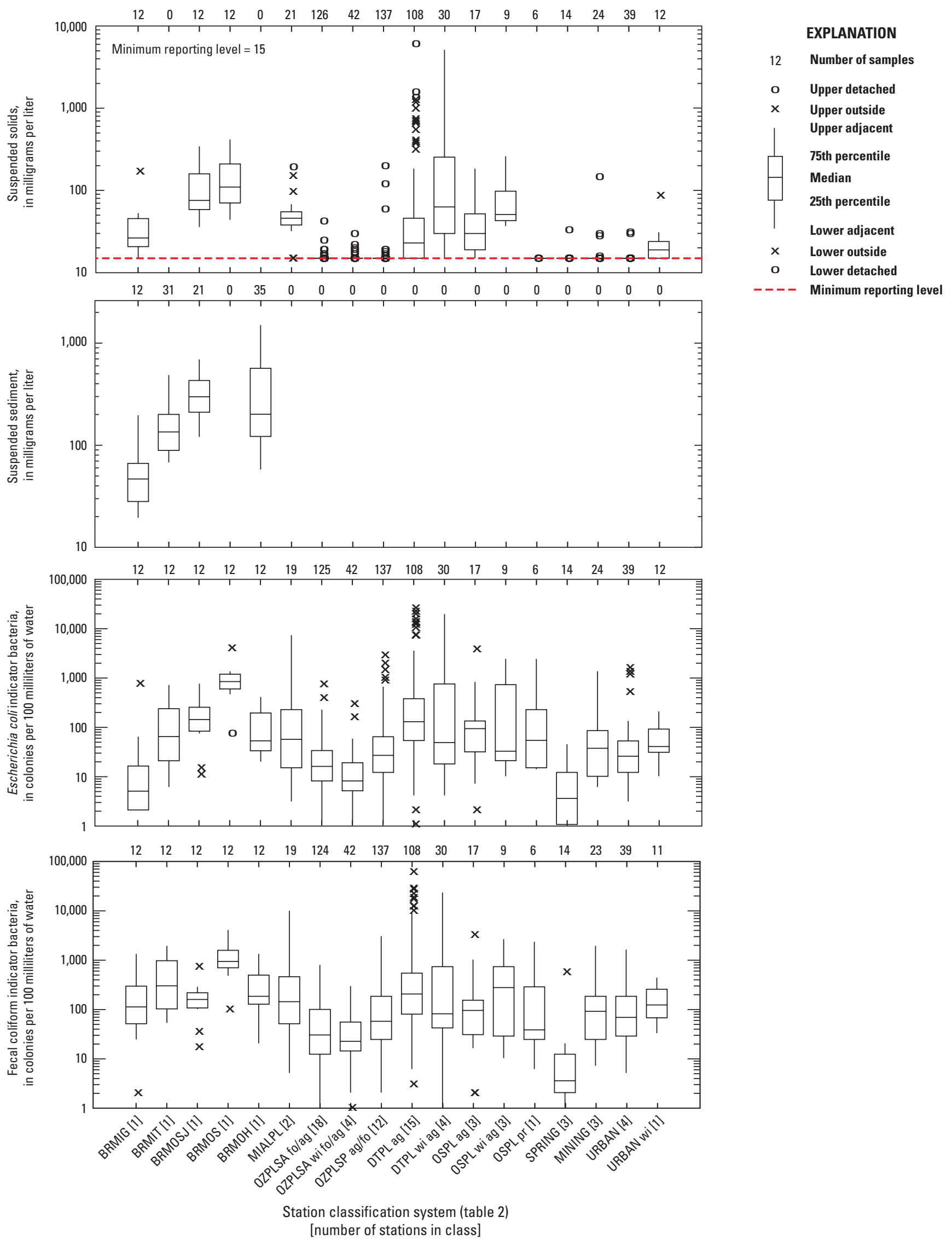

Figure 5. Distribution of physical properties, suspended-solids concentrations, suspended-sediment concentrations, and indicator bacteria densities in samples from 78 stations, water year 2012.-Continued 

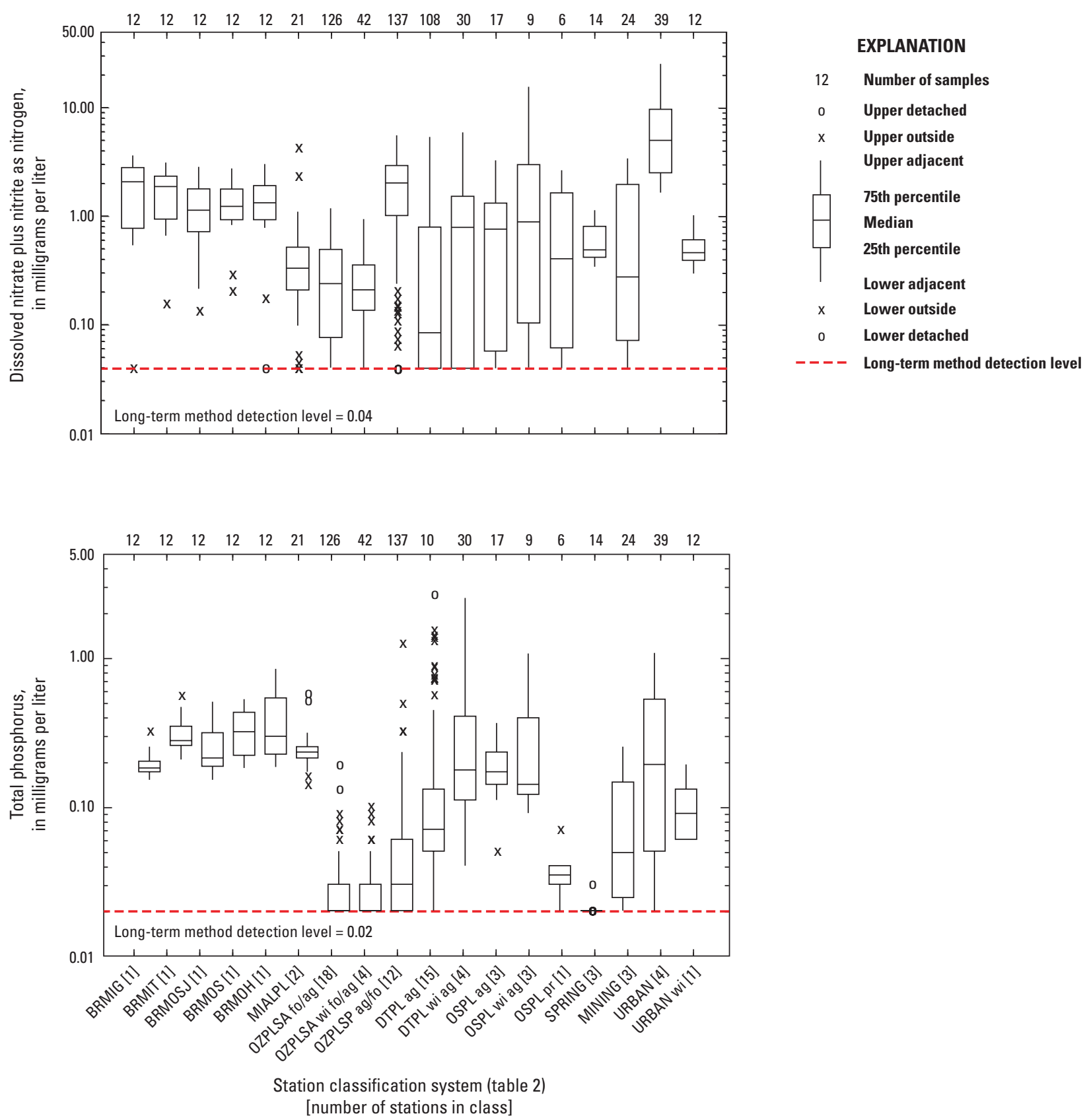

Figure 6. Distribution of dissolved nitrate plus nitrite as nitrogen and total phosphorus concentrations in samples from 78 stations, water year 2012. 

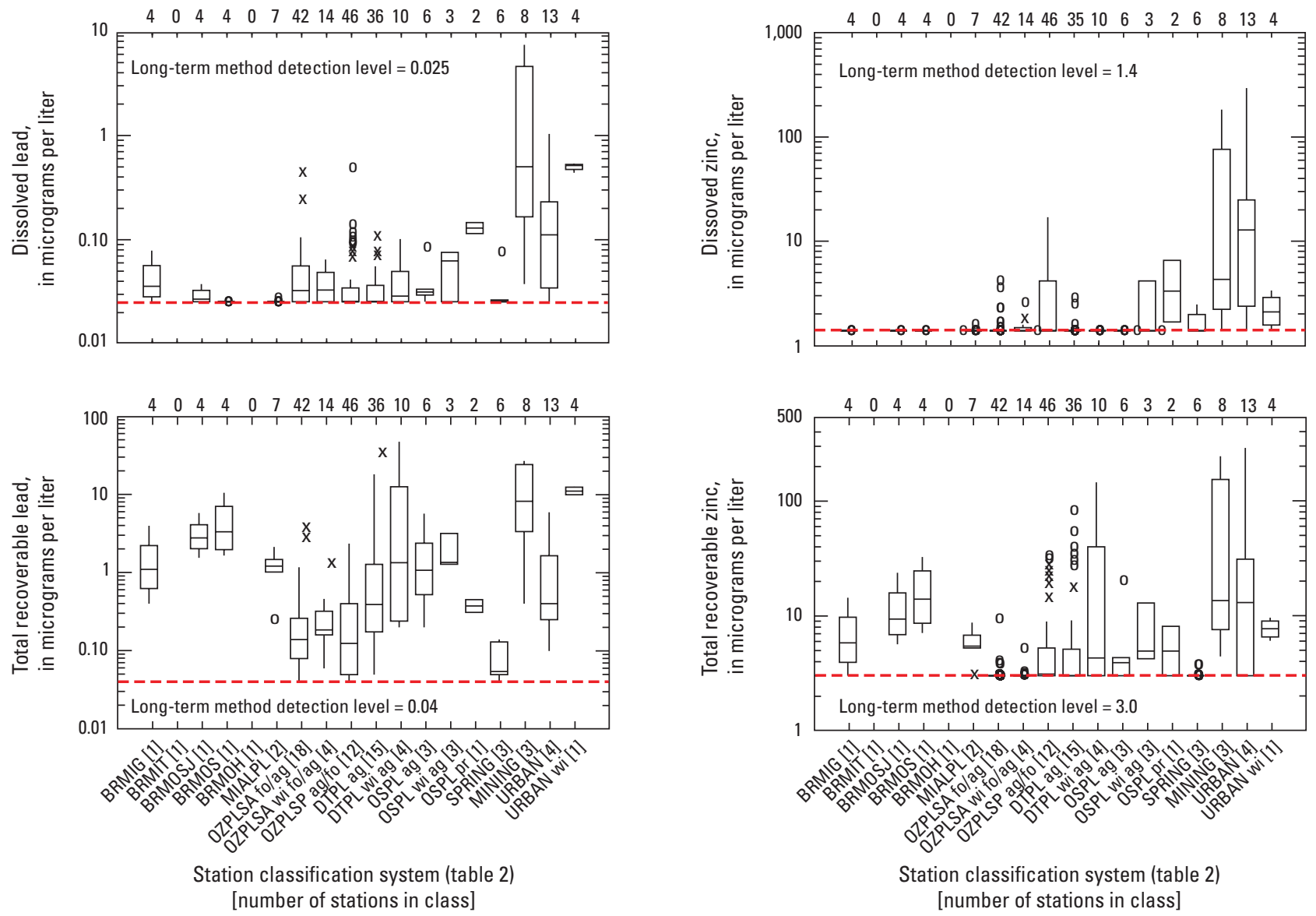

\section{EXPLANATION}

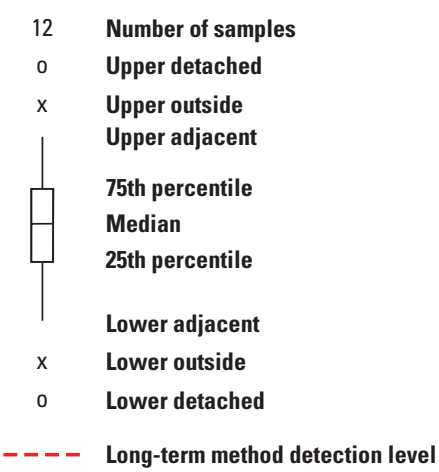

Figure 7. Distribution of dissolved and total recoverable lead and zinc concentrations from 78 stations, water year 2012. 

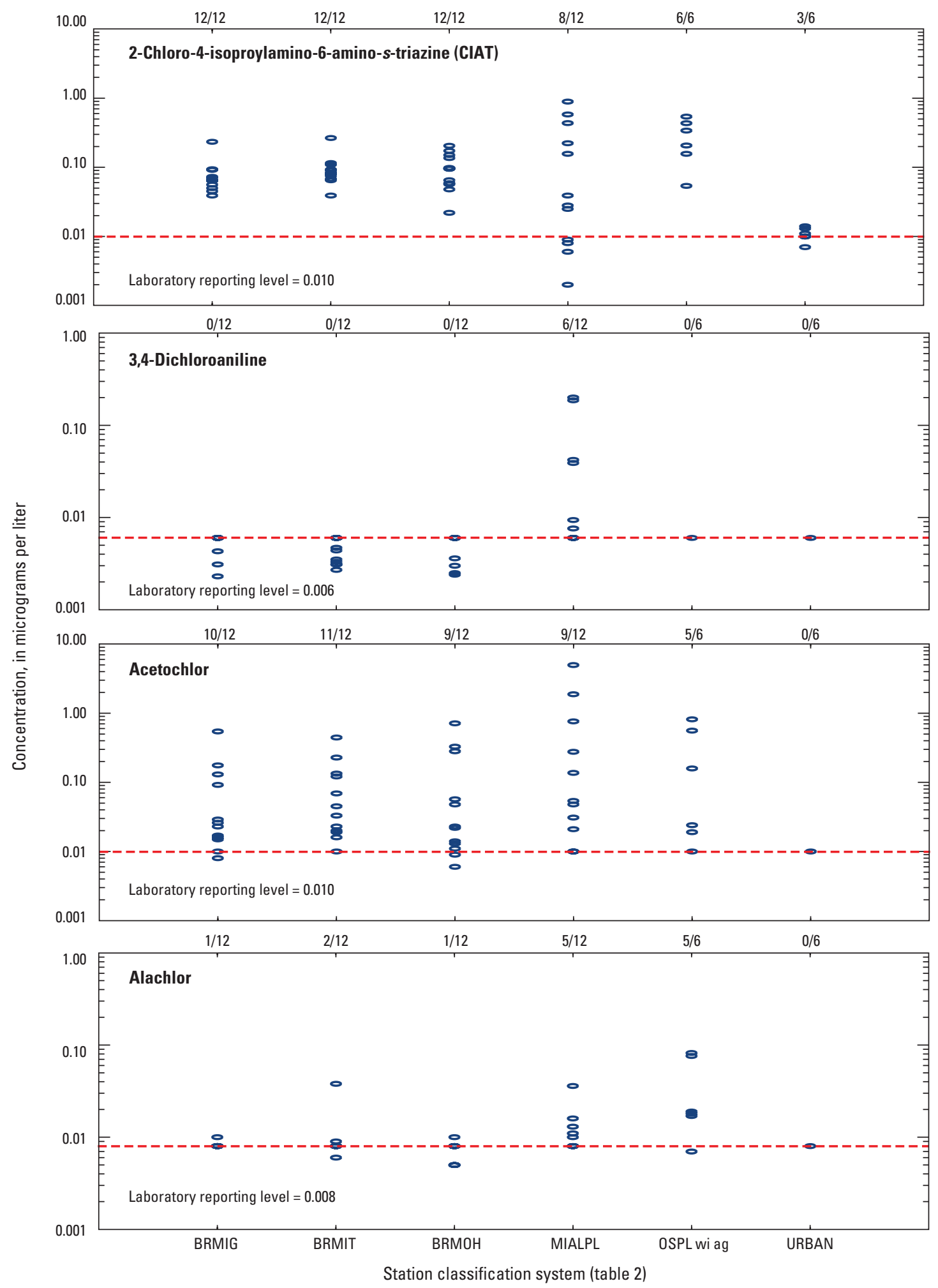

EXPLANATION

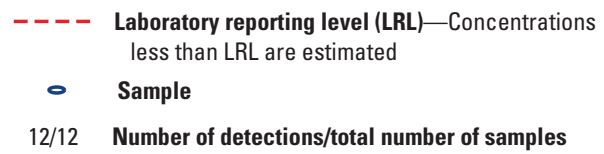

Figure 8. Detection of select pesticides from selected stations, water year 2012. 

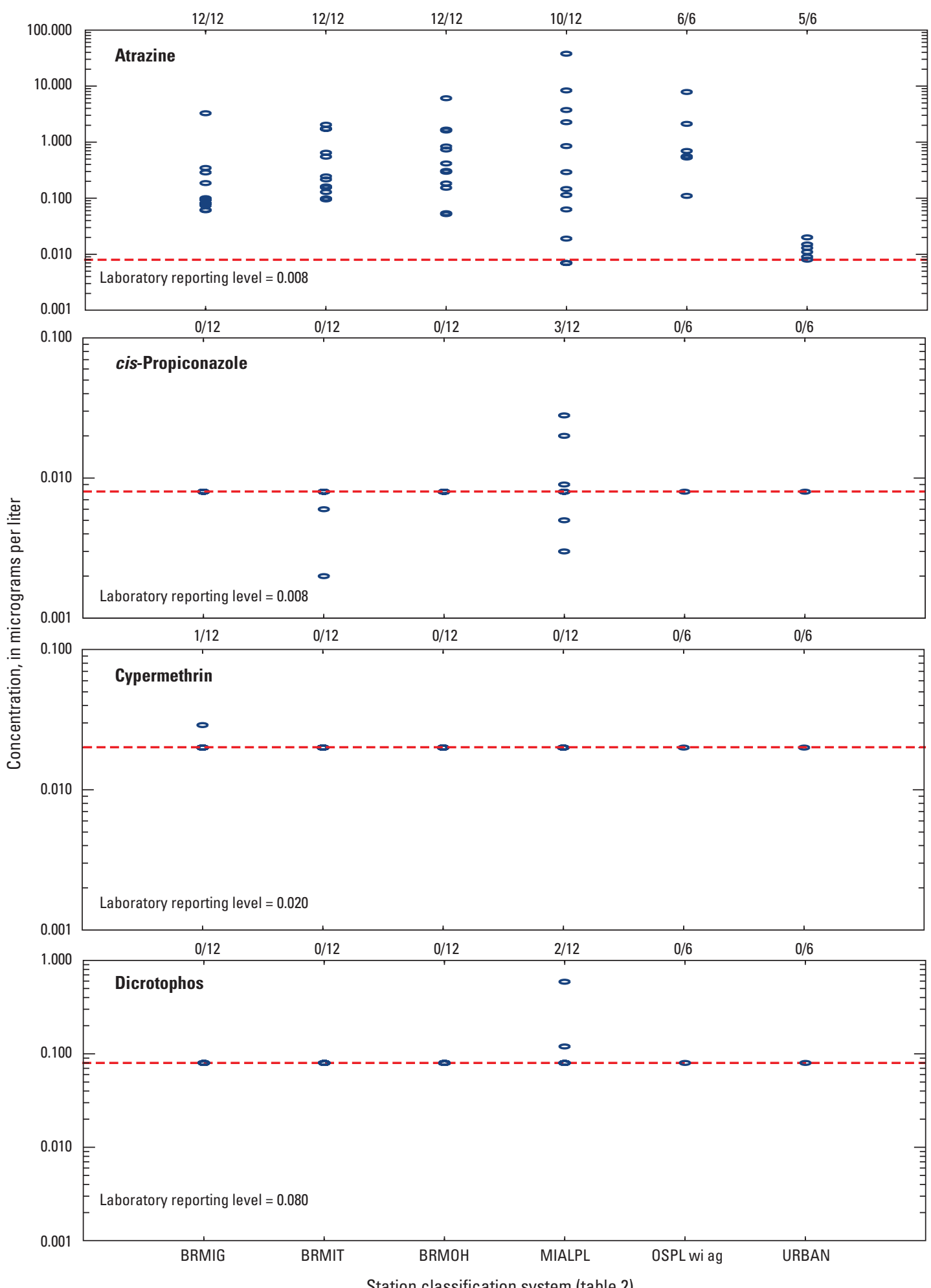

\section{EXPLANATION}

Laboratory reporting level (LRH)-Concentrations less than LRL are estimated

- Sample

12/12 Number of detections/total number of samples

Figure 8. Detection of select pesticides from selected stations, water year 2012.-Continued 


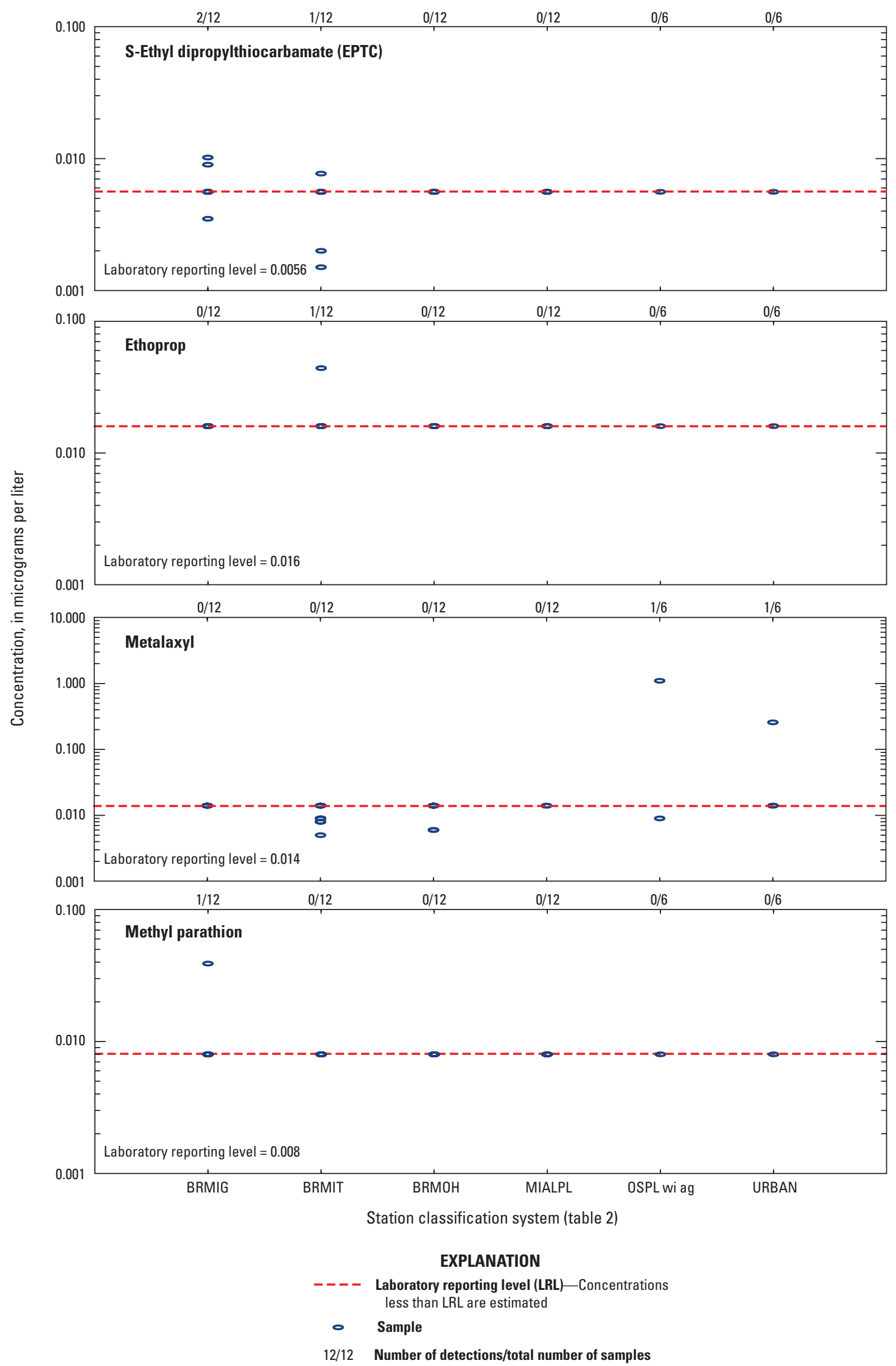

Figure 8. Detection of select pesticides from selected stations, water year 2012.-Continued 


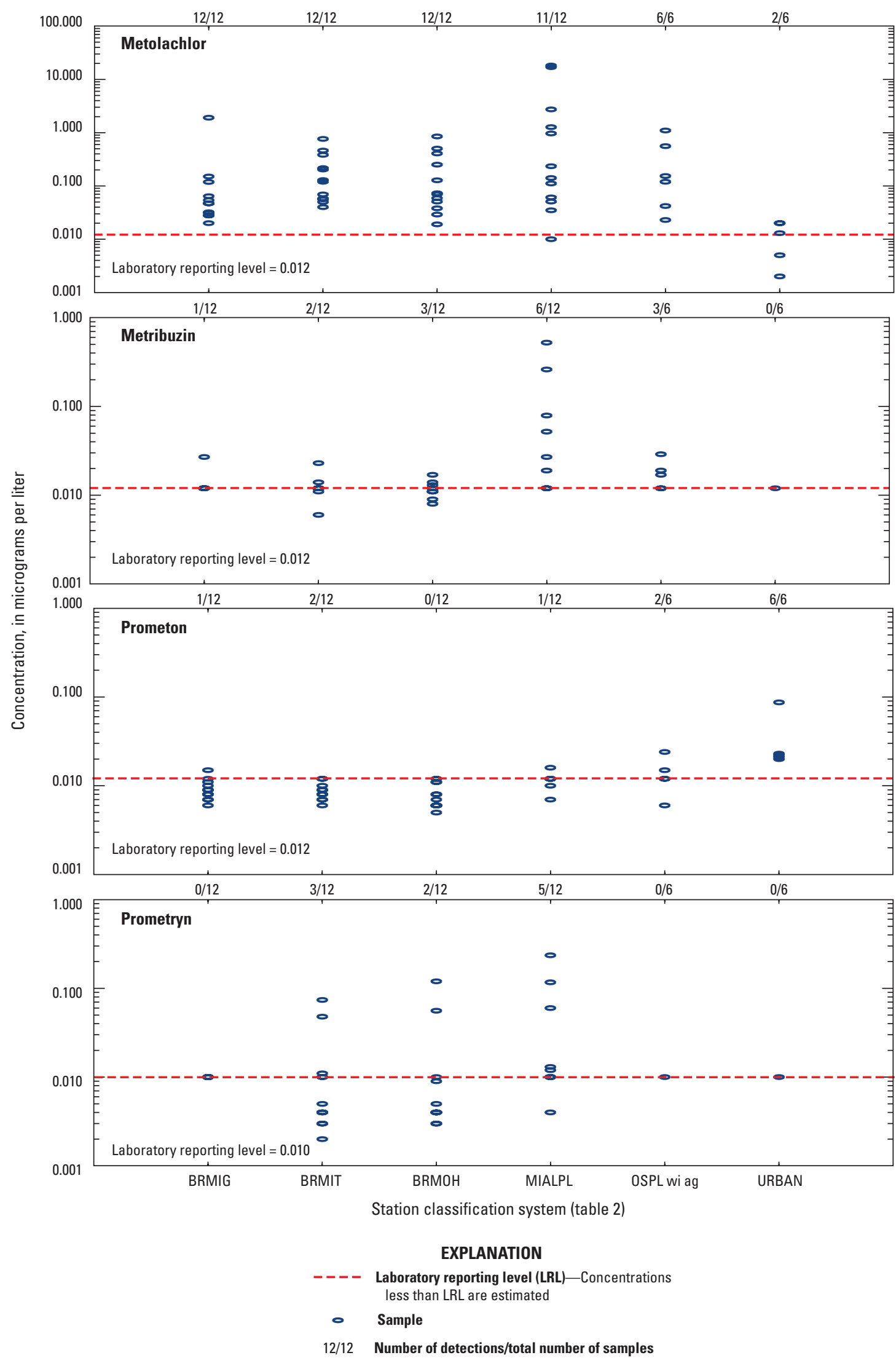

Figure 8. Detection of select pesticides from selected stations, water year 2012.—Continued 

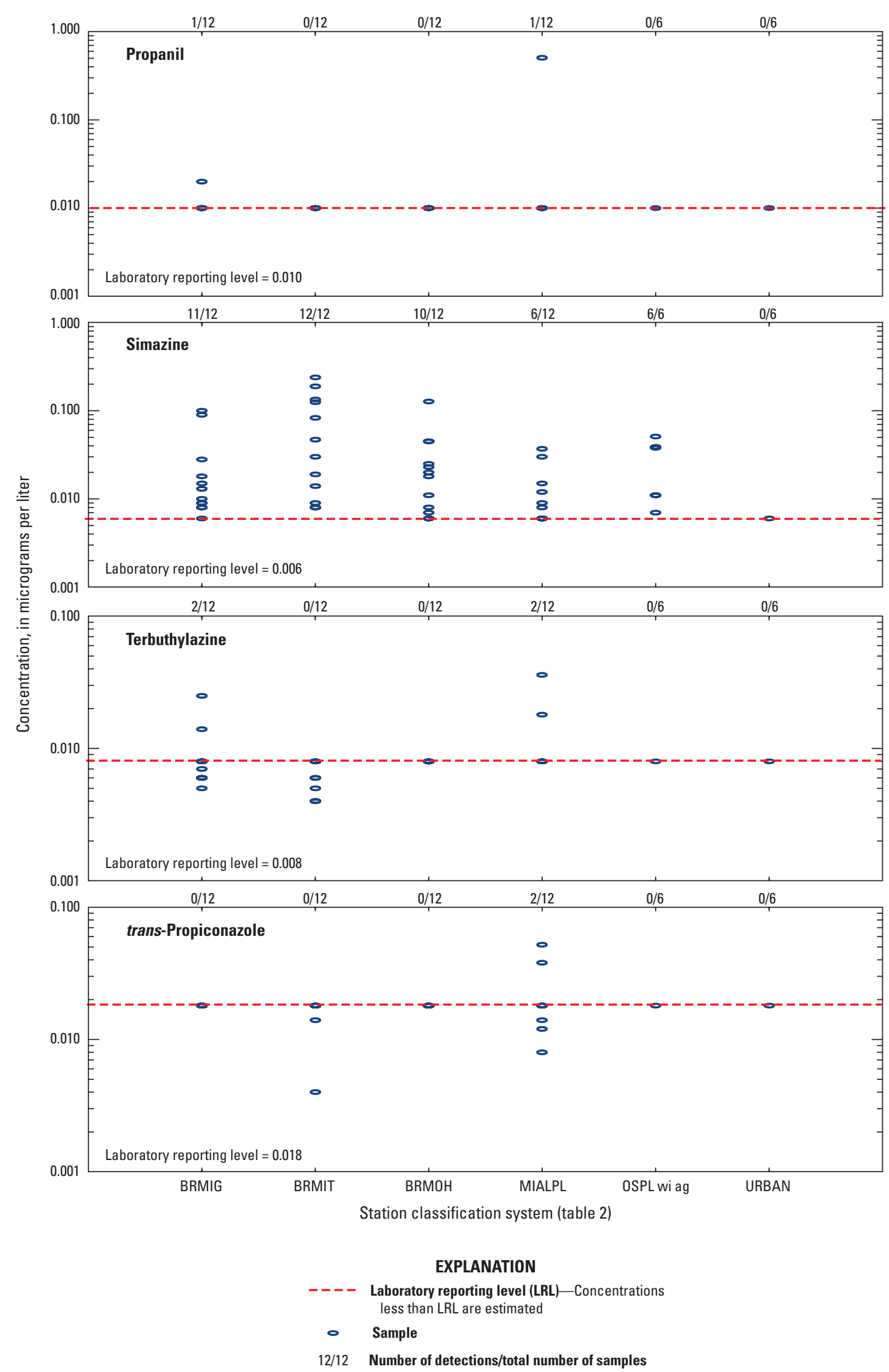

Figure 8. Detection of select pesticides from selected stations, water year 2012.—Continued 
total recoverable lead were largest at the URBAN wi station, and median dissolved zinc concentrations were largest in samples collected at URBAN stations. MINING stations had the largest median concentration of total recoverable zinc.

\section{Concentration and Detection Frequency of Select Pesticides from Selected Stations}

Samples for the analysis of dissolved pesticides were collected at seven stations in the AWQMN, including three of the five Big River stations (BRMIG, BRMIT, and BRMOH), both stations in the MIALPL, one OSPL wi ag station, and one URBAN station. Data from 20 compounds detected at concentrations greater than the LRL at 1 or more stations are presented graphically in this report (fig. 8). The most frequently detected pesticides were CIAT, acetochlor, alachlor, atrazine, metolachlor, metribuzin, and simazine. The concentrations for all pesticide compounds analyzed for all stations were less than $1.00 \mu \mathrm{g} / \mathrm{L}$ except acetochlor, atrazine, metalaxyl, and metolachlor. Acetochlor concentrations ranged from 0.010 to $4.97 \mu \mathrm{g} / \mathrm{L}$. Atrazine concentrations ranged from 0.008 to $37.6 \mu \mathrm{g} / \mathrm{L}$. Metalaxyl concentrations ranged from 0.005 to $1.10 \mu \mathrm{g} / \mathrm{L}$. Metolachlor concentrations ranged from 0.002 to $18.2 \mu \mathrm{g} / \mathrm{L}$. Of the 20 pesticide compounds with concentrations greater than the LRL, 12 had largest concentrations at the MIALPL stations (fig. 8).

\section{References Cited}

Barr, M.N., 2010, Quality of surface water in Missouri, water year 2009: U.S. Geological Survey Open-File Report 2010-1233, 22 p., accessed May 2013 at http://pubs.usgs. gov/of/2010/1233/.

Barr, M.N., 2011, Quality of surface water in Missouri, water year 2010: U.S. Geological Survey Data Series 636, 21 p., accessed May 2013 at http://pubs.usgs.gov/ds/636/.

Barr, M.N., 2012, Quality of surface water in Missouri, water year 2011: U.S. Geological Survey Data Series 734, 22 p., accessed May 2013 at http://pubs.usgs.gov/ds/734/.

Barr, M.N., and Davis, J.V., 2010, Surface-water quality conditions and long-term trends at selected sites within the ambient water-quality monitoring network in Missouri, water years 1993-2008: U.S. Geological Survey Scientific Investigations Report 2010-5078, 42 p.

Childress, C.J.O., Foreman, W.T., Connor, B.F., and Maloney, T.J., 1999, New reporting procedures based on longterm method detection levels and some considerations for interpretations of water-quality data provided by the U.S Geological Survey National Water Quality Laboratory: U.S. Geological Survey Open-File Report 99-193, 19 p.
Fenneman, N.M., 1938, Physiography of eastern United States: New York, McGraw-Hill Book Co., Inc., 689 p.

Fishman, M.J., ed., 1993, Methods of analysis by the U.S. Geological Survey National Water Quality Laboratory - Determination of inorganic and organic constituents in water and fluvial sediments: U.S. Geological Survey Open-File Report 93-125, 217 p.

Garbarino, J.R., Kanagy, L.K., and Cree, M.E., 2006, Determination of elements in natural-water, biota, sediment and soil samples using collision/reaction cell inductively coupled plasma-mass spectrometry: U.S. Geological Survey Techniques and Methods, book 5, chap. B1, 88 p.

Guy, H.P., 1969, Laboratory theory and methods for sediment analysis: U.S. Geological Survey Techniques of Water-Resources Investigations, book 5, chap. C1, accessed May 2013 at http://pubs.usgs.gov/twri/twri5c1/.

Helsel, D.R., and Hirsch, R.M., 2002, Statistical methods in water resources: U.S. Geological Survey Techniques of Water-Resources Investigations, book 4, chap. A3, accessed May 2013 at $h t t p: / / p u b s . u s g s . g o v / t w r i / t w r i 4 a 3 /$.

Missouri Department of Natural Resources, 2012a, Missouri water quality report (Section 305(b) Report), accessed August 2013 at $h t t p: / / w w w . d n r . m o . g o v / e n v / w p p /$ waterquality/305b/index.html.

Missouri Department of Natural Resources, 2012b, Missouri water quality standards - Chapter 7, Water quality: Jefferson City, Missouri, Clean Water Commission, $150 \mathrm{p}$.

Myers, D.N., Stoeckel, D.M., Bushon, R.N., Francy, D.S., and Brady, A.M.G., 2007, Fecal indicator bacteria (ver. 2.0): U.S. Geological Survey Techniques of Water-Resources Investigations, book 9, chap. A7, accessed May 2013 at http://pubs.water.usgs.gov/twri9A7/.

National Drought Mitigation Center, University of NebraskaLincoln, 2013, U.S. drought monitor data archives, accessed October 2013 at http://droughtmonitor.unl.edu.

National Oceanic and Atmospheric Administration, 2013a, State of the climate - National overview for annual 2012, accessed August 2013 at http://www.ncdc.noaa.gov/sotc/ national/2012/13.

National Oceanic Atmospheric Administration, 2013b, 2012 Missouri climate summary: National Climatic Data Center database, accessed August 2013 at http://www.ncdc.noaa. gov/cag/.

Otero-Benítez, W., and Davis, J.V., 2009a, Quality of surface water in Missouri, water year 2007: U.S. Geological Survey Open-File Report 2009-1096, 19 p., accessed May 2012 at http://pubs.usgs.gov/of/2009/1096/. 
Otero-Benítez, W., and Davis, J.V., 2009b, Quality of surface water in Missouri, water year 2008; U.S. Geological Survey Open-File Report 2009-1214, 18 p., accessed May 2012 at http://pubs.usgs.gov/of/2009/1214/.

Patton, C.J., and Truitt, E.P., 1992, Methods of analysis by the U.S. Geological Survey National Water Quality Laboratory-Determination of total phosphorus by a Kjeldahl digestion method and an automated colorimetric finish that includes dialysis: U.S. Geological Survey Open-File Report 92-146, 39 p.

Patton, C. J., and Kryskalla, J. R., 2011, Colorimetric determination of nitrate plus nitrite in water by enzymatic reduction, automated discrete analyzer methods: U.S. Geological Survey Techniques and Methods, book 5, chap. B8, 48 p.

Sandstrom, M.W., Stroppel, M.E., Foreman, W.T., and Schroeder, M.P., 2001, Methods of analysis by the U.S. Geological Survey National Water Quality Laboratory-Determination of moderate-use pesticides and selected degradates in water by $\mathrm{C}-18$ solid-phase extraction and gas chromatography/mass spectrometry: U.S. Geological Survey WaterResources Investigations Report 01-4098, 70 p.

U.S. Census Bureau, 2012, U.S. population estimates, accessed August 2013 at http://www.census.gov/.

U.S. Environmental Protection Agency, 1997, Guidelines for preparation of the comprehensive state water quality assessments (305(b) reports) and electronic updates: Washington, D.C., Office of Water, EPA-841-B97-002A, variously paged, accessed May 2013 at http://www.epa.gov/owow/ monitoring/guidelines.html.

U.S. Geological Survey, 1964-2005, Water resources dataMissouri: variously paged.

U.S. Geological Survey, 2006, Collection of water samples (ver. 2.0): U.S. Geological Survey Techniques of WaterResources Investigations, book 9, chap. A4, accessed May 2013 at http://pubs.water.usgs.gov/twri9A4.

U.S. Geological Survey, 2006-2010, Water resources data for the United States: Water-Data Report, accessed May 2013 at http://wdr.water.usgs.gov/.

U.S. Geological Survey, variously dated, National field manual for the collection of water-quality data: U.S. Geological Survey Techniques of Water-Resources Investigations, book 9, chaps. A1-A9, accessed May 2013 at http://pubs. water.usgs.gov/twri9A.

Wilde, F.D., ed., chapter sections variously dated, Field measurements: U.S. Geological Survey Techniques of Water-Resources Investigations, book 9, chap. A6, accessed May 2013 at http://pubs.water.usgs.gov/twri9A6/.
Wilde, F.D., Radtke, D.B., Gibs, Jacob, and Iwatsubo, R.T., eds., 2004, Processing of water samples (ver. 2.2): U.S. Geological Survey Techniques of Water-Resources Investigations, book 9, chap. A5, accessed May 2013 at http://pubs.water.usgs.gov/twri9A5/.

Zaugg, S.D., Sandstrom, M.W., Smith, S.G., and Fehlberg, K.M., 1995, Methods of analysis by the U.S. Geological Survey National Water Quality Laboratory-Determination of pesticides in water by $\mathrm{C}-18$ solid-phase extraction and capillary-column gas chromatography/mass spectrometry with selected-ion monitoring: U.S. Geological Survey Open-File Report 95-181, 49 p.
Publishing support provided by: Rolla Publishing Service Center

For more information concerning this publication, contact: Director, USGS Missouri Water Science Center 1400 Independence Road Rolla, MO 65401

(573) 308-3667

Or visit the Missouri Water Science Center Web site at: http://mo.water.usgs.gov 



\section{$\frac{\mathbb{2}}{3}$}

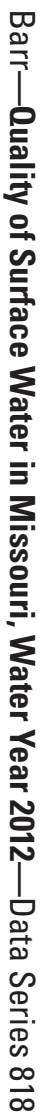

